RHO-BWI.DP..053

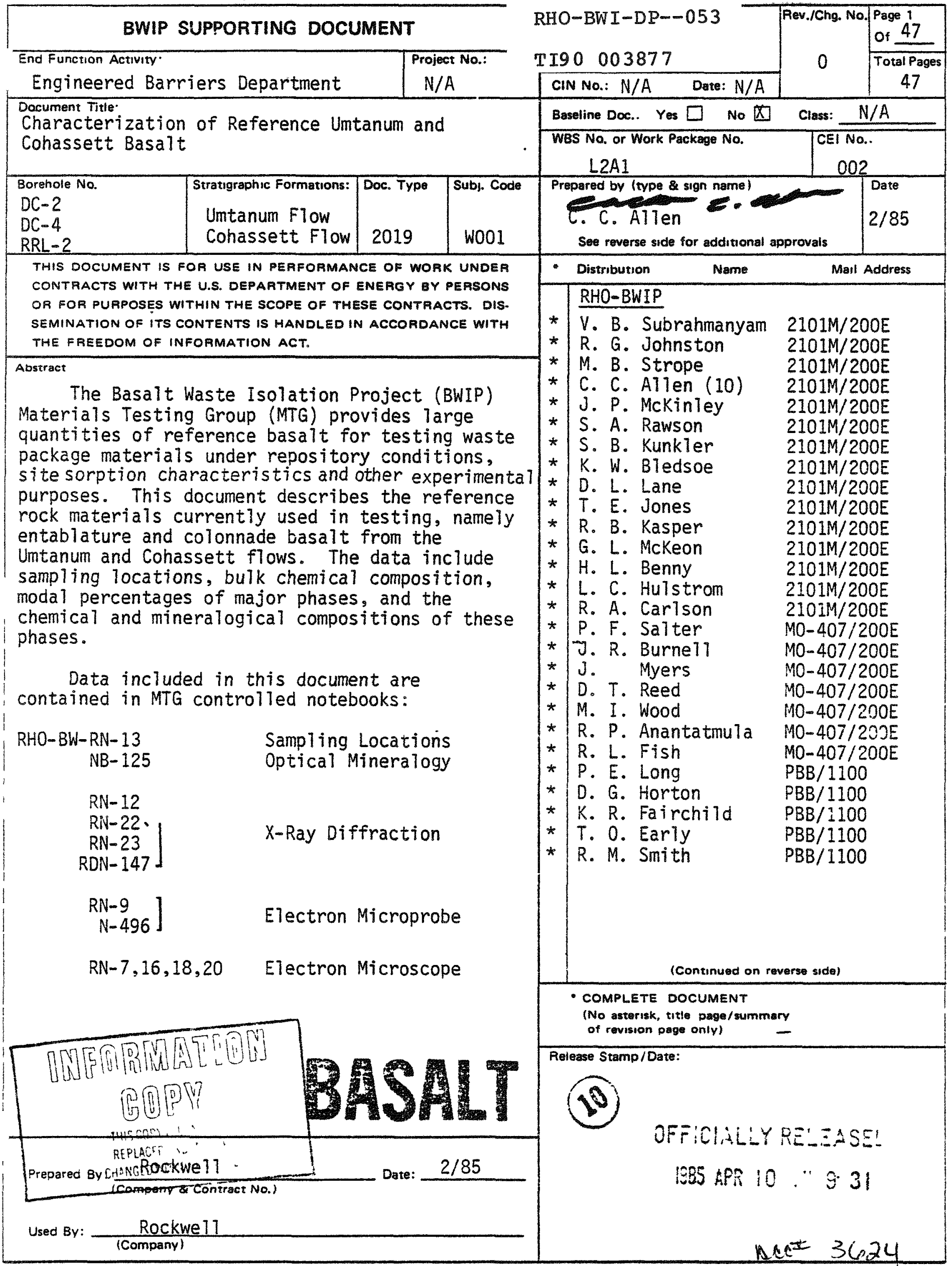




\section{DISCLAIMER}

This report was prepared as an account of work sponsored by an agency of the United States Government. Neither the United States Government nor any agency Thereof, nor any of their employees, makes any warranty, express or implied, or assumes any legal liability or responsibility for the accuracy, completeness, or usefulness of any information, apparatus, product, or process disclosed, or represents that its use would not infringe privately owned rights. Reference herein to any specific commercial product, process, or service by trade name, trademark, manufacturer, or otherwise does not necessarily constitute or imply its endorsement, recommendation, or favoring by the United States Government or any agency thereof. The views and opinions of authors expressed herein do not necessarily state or reflect those of the United States Government or any agency thereof. 


\section{DISCLAIMER}

Portions of this document may be illegible in electronic image products. Images are produced from the best available original document. 


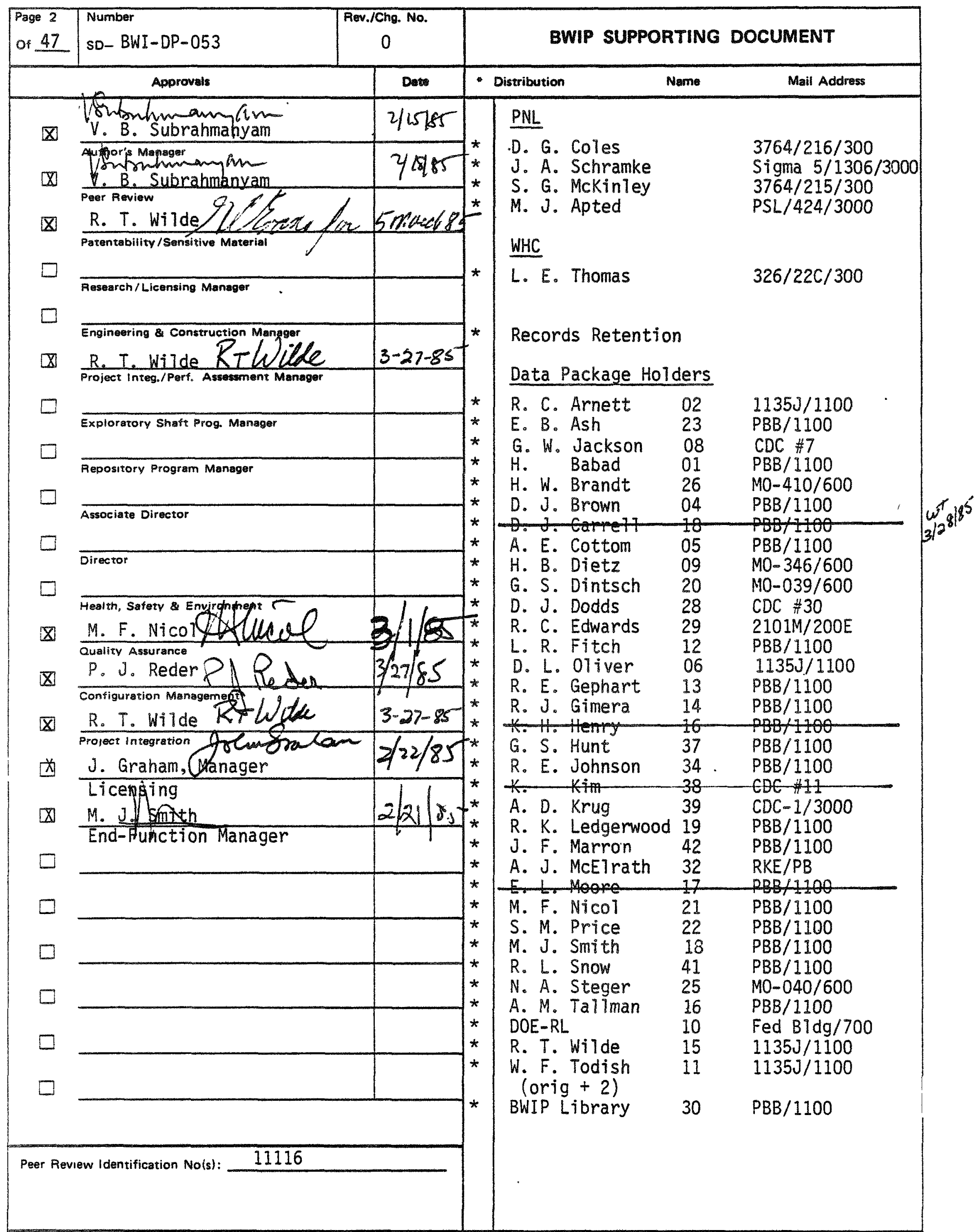




\title{
CHARACTERIZATION OF REFERENCE UMTANUM AND COHASSETT BASALT
}

\author{
C. C. Alten \\ R. G. Johnston \\ M. B. Strope \\ Materials Testing Group \\ Basalt Waste Isolation Project \\ Rockwell Hanford Operations \\ Richland, Washington
}

\section{DISCLAIMER}

This report was prepared as an account of work sponsored by an agency of the United States Government. Neither the United States Government nor any agency thereof, nor any of their employees, makes any warranty, express or implied, or assumes any legal liability or responsibility for the accuracy, completeness, or usefulness of any information, apparatus, product, or process disclosed, or represents that its use would not infringe privately owned rights. Reference herein to any specific commercial product, process, or service by trade name, trademark, manufacturer, or otherwise does not necessarily constitute or imply its endorsement, recommendation, or favoring by the United States Government or any agency thereof. The views and opinions of authors expressed herein do not necessarily state or reflect those of the United States Government or any agency thereof. 
REV 0

Introduction

The llcensing. of a nuclear waste repository in basalt requires a considerable number of experiments to be performed in the presence of host rock to evaluate the waste package materfals performance and to determine the radionuclide sorption characteristies of the site. Large quantities of the host rock are required to perform these experiments. Unfortunately, it is very difficult to obtain such large quantities of the host rock from in-situ sources because the proposed repository is at depth of approximately $1.000 \mathrm{~m}$. In response to this problem, sultable basalt. reference Umtanum entablature (RUE), was collected from an outcrop and shown to closely match the chemistry of the repository level basalt (Noonan et a 1.. 1981). It is avallable in the massive amounts (megagram quantities) that are required for aste package testing and other Basalt Waste Isolation Project experimentation. Samples of RUE-1 were collected in the spring of 1980 at Emerson Nipple. located in the SW $1 / 4$ of the NE $1 / 4$ of Section 12, TI3N, RZBE, elevation $240 \mathrm{~m}$ (Figure 1 and Myers ot a 1.. 1979, Plate III-3a). Additional samples from the same location, collected in 1982, are designated RUE-2. A nearby reference Untanum colonnade (RUC) site has also been designated. Samples of RUC-1 were coll lected in 1980.

Reference sampling sites for Cohassett entablature (RCE) and colonnade (RCC) were established at an exposure in Sentinel Gap. located in the NE 1/4 of the SE 1/4 of Section 10, TI5N, R23E, elevation $308 \mathrm{~m}$ (FIgure 1 and Myers, et 1.. 1979, Plate III-3b). As of the present report, four sets of reference Cohassett entablature basalt and three sets of reference Cohassett colonnade basalt had been collected.

The reference basalt samples are being used in hydrothermal and sorption experiments to support waste package testing and other investigations by or for the BWIP. The baseline data provided below 111 facilitate interpretation of the results.

Reference Umtanum Entablature Basait

The analyses for the Umtanum entablature basalt included optical petrography and point counting, X-ray dfffraction (XRD), scanning electron microscopy (SEM), scanning transmission electron microscopy (STEM), energy- 
REV 0

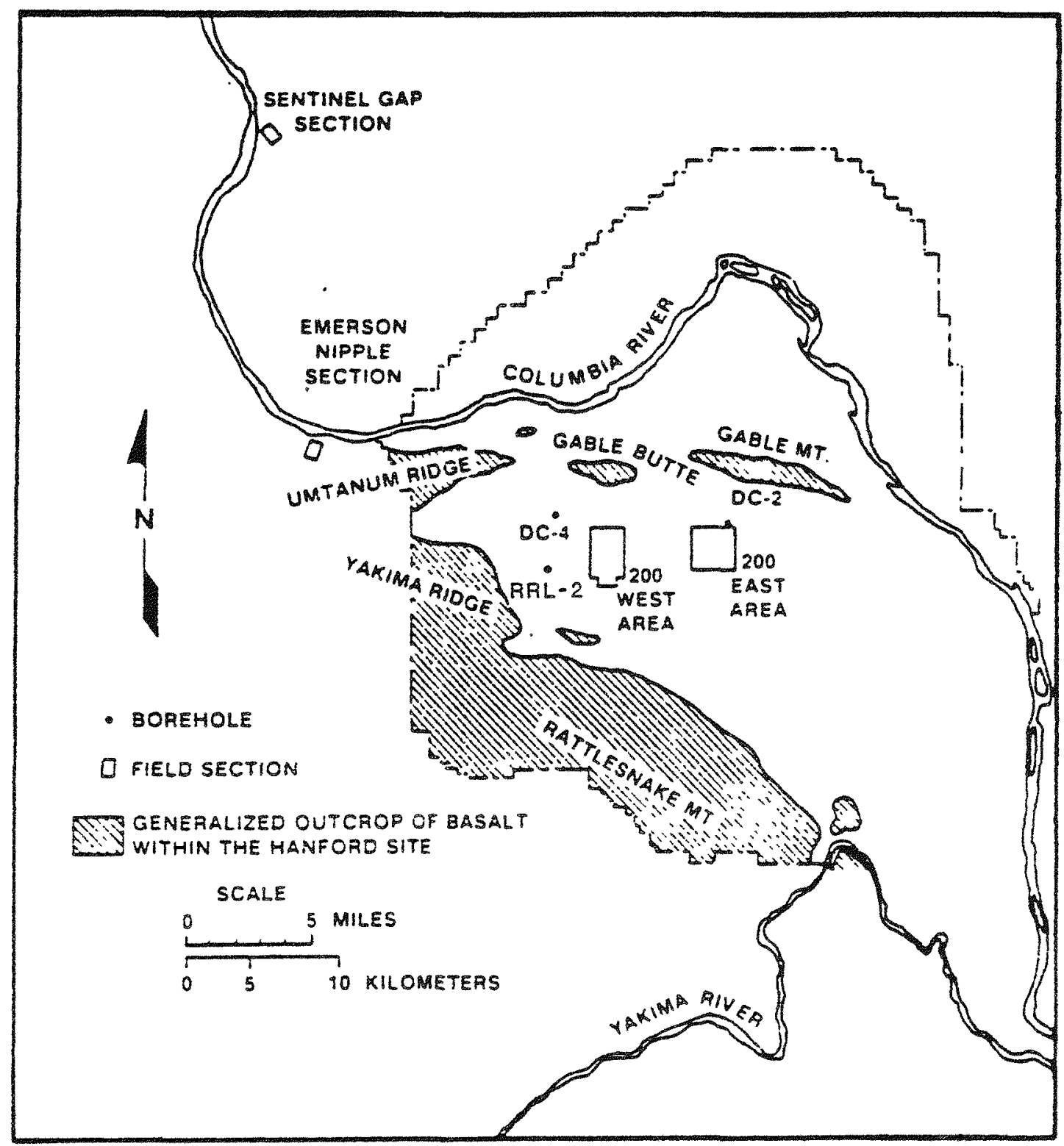

Figure 1. Map of sampling locations (modified from Myers, et a1., 1979, Figure III-29). 
REV 0

dispersive spectroscopy (EDS), electron microprobe (EMP), and bulk chemical composition by wet chemistry and X-ray fluorscence (XRF). The petrographic and EMP data are taken from Noonan, et al.o (1981) and Palmer, et al., (1982). Who measured several thousand points on a number of sections. The wet chemical numbers were obtained on splits from the outcrop.

Petrographic and Microprobe Analysts

The reference Untanum entablature (RUE) is characterized by abundant glassy mesostasis and titaniferous magnetite dendrites (Figure 2). Plagioclase is the most abundant sflicate mineral (Tables 1, 2) and is very constant in composition (An49-51). Clinopyroxene is the second most abundant phase and shows the chemical varfeties normally found in basaltic rocks. Most pyroxene is in the augite compositional range with the exception of minor pigeonite, subcalcic augite, and ferroaugite. The major opaque phase is titaniferous magnetite which is nearly constant in composition ranging from $28-32$ w.\% $\mathrm{TiO}_{2}$ (Noonan et a 1.. 1981, p. 53). By far the most abundant material in the basalt is the mesostasis (Table 3). This is a Sirich giass containing micron-size magnetite, pyroxene and apatite crystals (A) 1 en and Strope, 1983, p. 2).

X-ray Diffraction

$X$-ray diffractograms of the Untanum entablature basa it from a core sample (DC-4, $3,730.5$ ) and from a surface sample (RUE-2) are compared in Figure 3. The most abundant phase in the basalt is plagioclase feldspar, as indicated by the relative intensities of its major diffraction peaks. The plagioclase diffraction pattern provides good matches with two Powder Diffraction File (PDF) patterns (18-1202: An 57.2 , Ab31.5, Or. 35 ; 9-465: $A n_{64.5}, A_{37.2}, 0 r_{2.8}$, listed as intermediate and low sodian anorthite. respectively. Small differences in the peak positions relative to the reference dffractograms are consistent ith the composition of the plagloclase (more sodic and potassic than the reference materials) as determined by electron microprobe. The remainder of the peaks may be accounted for by the pyroxene phases augite (PDF 24-201, Ca[Fe,Mg]Si2 $\mathrm{O}_{6}$, and

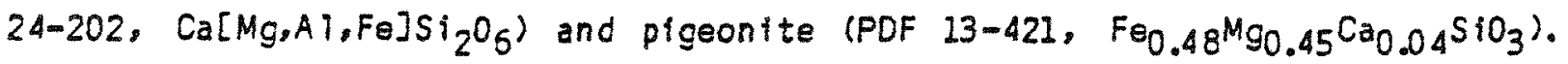
Due to the relatively small quantity present and overlaps ith the major diffraction peaks of the pyroxenes, the presence of titaniferous magnetite 


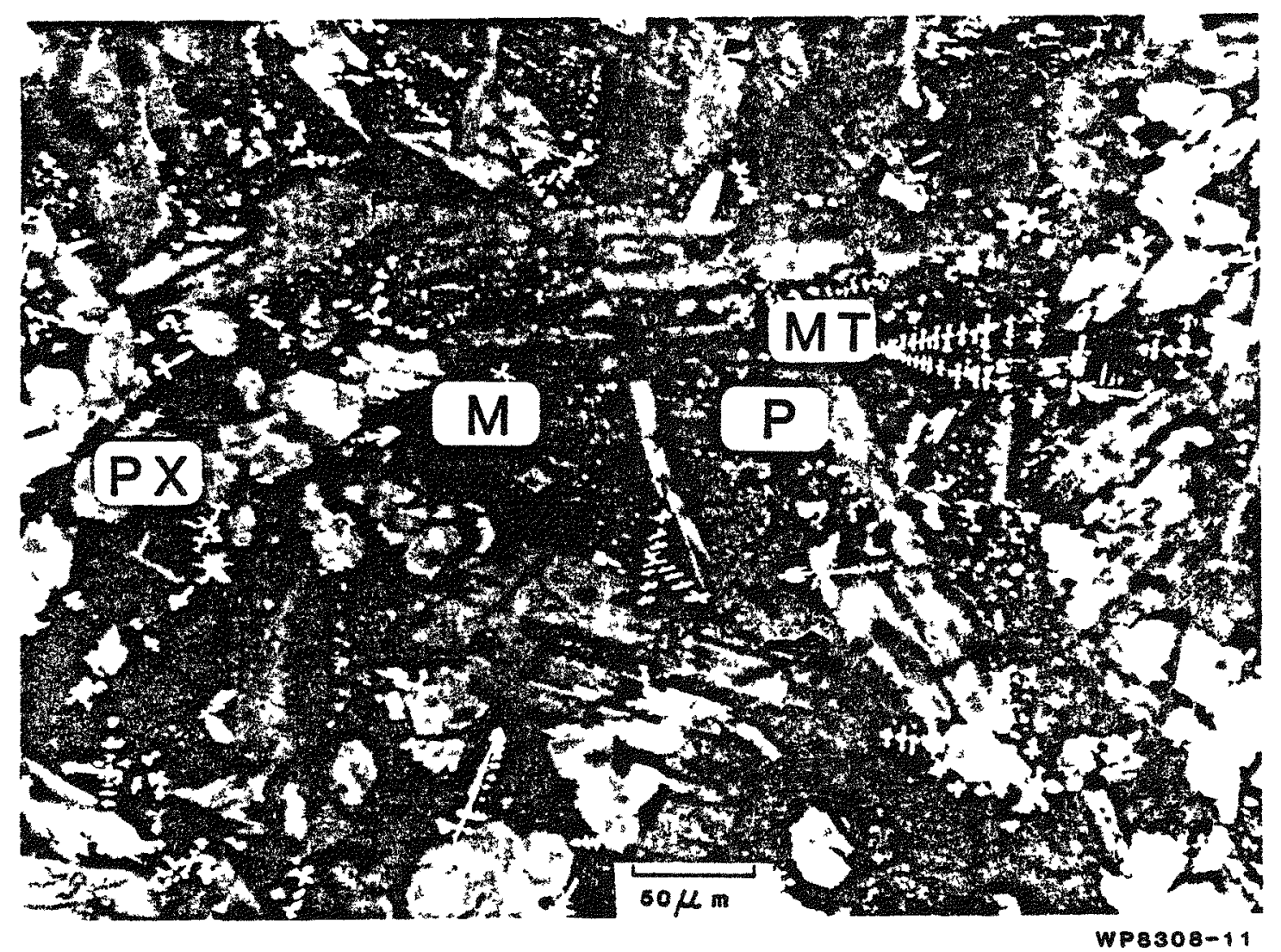

Figure 2. Reflected light photomicrograph of RUE-1 basalt. Plagioclase ( $P$ ), pyroxene (PX), mesostasis (M), magnetite (MT). 
SD $-B W I-D P=053$

REV 0

Table 1. Point Count Data for RUE=1.

\begin{tabular}{|c|c|c|c|c|c|c|}
\hline Run No. & 1 & 2 & 3 & 4 & Total & $\sigma$ \\
\hline $\begin{array}{l}\text { Number of points } \\
\text { per run }\end{array}$ & 614 & 571 & 671 & 713 & 2.569 & \\
\hline Phase & modal & modal $\%$ & modal $\%$ & modal $\%$ & modal \% & $+1=$ \\
\hline Plagloclase & 29.3 & 27.3 & 27.9 & 30.3 & 28.7 & 1.4 \\
\hline Pyroxene & 16.4 & 18.6 & 17.9 & 15.4 & 17.1 & 1.4 \\
\hline Mesostasis & 47.1 & 48.0 & 47.5 & 48.1 & 47.7 & 1.1 \\
\hline $\begin{array}{l}\text { Titanlferous } \\
\text { Magnetite }\end{array}$ & 4.72 & 4.90 & 5.96 & 4.91 & 5.12 & 0.50 \\
\hline $\begin{array}{l}\text { Aiteration } \\
\text { Products }\end{array}$ & 2.40 & 1.58 & 1.34 & 1.26 & 1.65 & 0.52 \\
\hline Total & 99.9 & 100.4 & 100.6 & 100.0 & 100.3 & \\
\hline
\end{tabular}

* Data from Palmer, et al., 1982. Table 2.

$\sigma=$ Standard Deviation 
$S D-B W I-D P-053$

REV 0

TABLE 2. Composition of Major Silicate Minerals* in the Umtanum Entablature (wt \%)

\begin{tabular}{|c|c|c|c|c|c|c|}
\hline \multirow[b]{2}{*}{ Oxide } & \multicolumn{2}{|c|}{ Plagioclase } & \multicolumn{2}{|c|}{ Pigeonite } & \multicolumn{2}{|c|}{ Augite } \\
\hline & RUE-1 & $D C-2,3131$ & RUE-1 & $D C-2,3131$ & RUE-1 & $D C-2,3131$ \\
\hline $\mathrm{SiO}_{2}$ & 55.5 & 56.1 & 50.9 & 51.5 & 49.4 & 50.1 \\
\hline $\mathrm{THO}_{2}$ & 0.11 & 0.13 & 0.58 & 0.61 & 1.15 & 0.94 \\
\hline $\mathrm{Al}_{2} \mathrm{O}_{3}$ & 27.2 & 26.6 & 0.82 & 0.72 & 1.89 & 2.03 \\
\hline $\mathrm{FeO}^{\mathrm{a}}$ & 0.70 & 0.90 & 23.5 & 22.5 & 17.9 & 15.3 \\
\hline Mno & Nob & ND & 0.53 & 0.48 & 0.46 & 0.48 \\
\hline $\mathrm{MgO}$ & 0.11 & 0.08 & 19.1 & 18.1 & 13.9 & 14.8 \\
\hline CaO & 9.57 & 9.76 & 5.2 & 6.27 & 15.2 & 15.1 \\
\hline $\mathrm{Na}_{2} \mathrm{O}$ & 4.97 & 5.09 & 0.07 & 0.09 & 0.25 & 0.28 \\
\hline $\mathrm{K}_{2} \mathrm{O}$ & 0.68 & 0.71 & ND & ND & ND & ND \\
\hline $\mathrm{P}_{2} \mathrm{O}_{5}$ & ND & ND & ND & ND & NO & NO \\
\hline $\mathrm{Cr}_{2} \mathrm{O}_{3}$ & ND & ND & $<0.05$ & $<0.05$ & $<0.05$ & $<0.05$ \\
\hline TOTAL & 98.9 & 99.4 & 200.7 & 100.3 & 100.2 & 99.0 \\
\hline \multirow[t]{3}{*}{ Mo 1\% } & An 51 & An 51 & En 53 & En 51 & En 40 & En 43 \\
\hline & $A b \quad 44$ & $A b \quad 45$ & Fs 37 & $F s 36$ & $F \subseteq 29$ & Fs 25 \\
\hline & or 5 & or 4 & Wo 10 & Wo 13 & Wo 31 & Wo 32 \\
\hline
\end{tabular}

*Microprobe date from Noonan et al., 1981, Table 2

a Ali iron reported as FeO

b ND = not detected 
$S D-B W I-D P-053$

REV 0

Table 3. Composition of Mesostasis* in the Umtanum Entablature (wt. $)^{a}$

\begin{tabular}{lcc}
\hline Oxide & RUE-1 & DC-2.3131 \\
\hline $\mathrm{SiO}_{2}$ & 61.2 & 69.4 \\
$\mathrm{THO}_{2}$ & 1.53 & 0.86 \\
$\mathrm{Al}_{2} \mathrm{O}_{3}$ & 12.5 & 13.7 \\
$\mathrm{FeO}^{\mathrm{b}}$ & 10.5 & 4.49 \\
$\mathrm{MnO}$ & 0.26 & $<0.05$ \\
$\mathrm{MgO}$ & 0.59 & $<0.05$ \\
$\mathrm{CaO}_{2}$ & 3.87 & 1.90 \\
$\mathrm{Na}_{2} \mathrm{O}$ & 7.1 & 7.5 \\
$\mathrm{~K}_{2} \mathrm{O}$ & 2.68 & 2.74 \\
$\mathrm{P}_{2} \mathrm{O}_{5}$ & 0.62 & 0.36 \\
$\mathrm{Cr}_{2} \mathrm{O}_{3}$ & $\mathrm{NOC}$ & $\mathrm{ND}$ \\
& & \\
$\mathrm{TOtal}^{\mathrm{C}}$ & 100.8 & 101.0 \\
\hline
\end{tabular}

* Microprobe data from Noonan, et al., 1981. Table 3.

a Average of five analyses (RUE-1): seven anaiyses $(D C-2,3131)$

b All iron reported as FeO

C ND $=$ Not detected. 


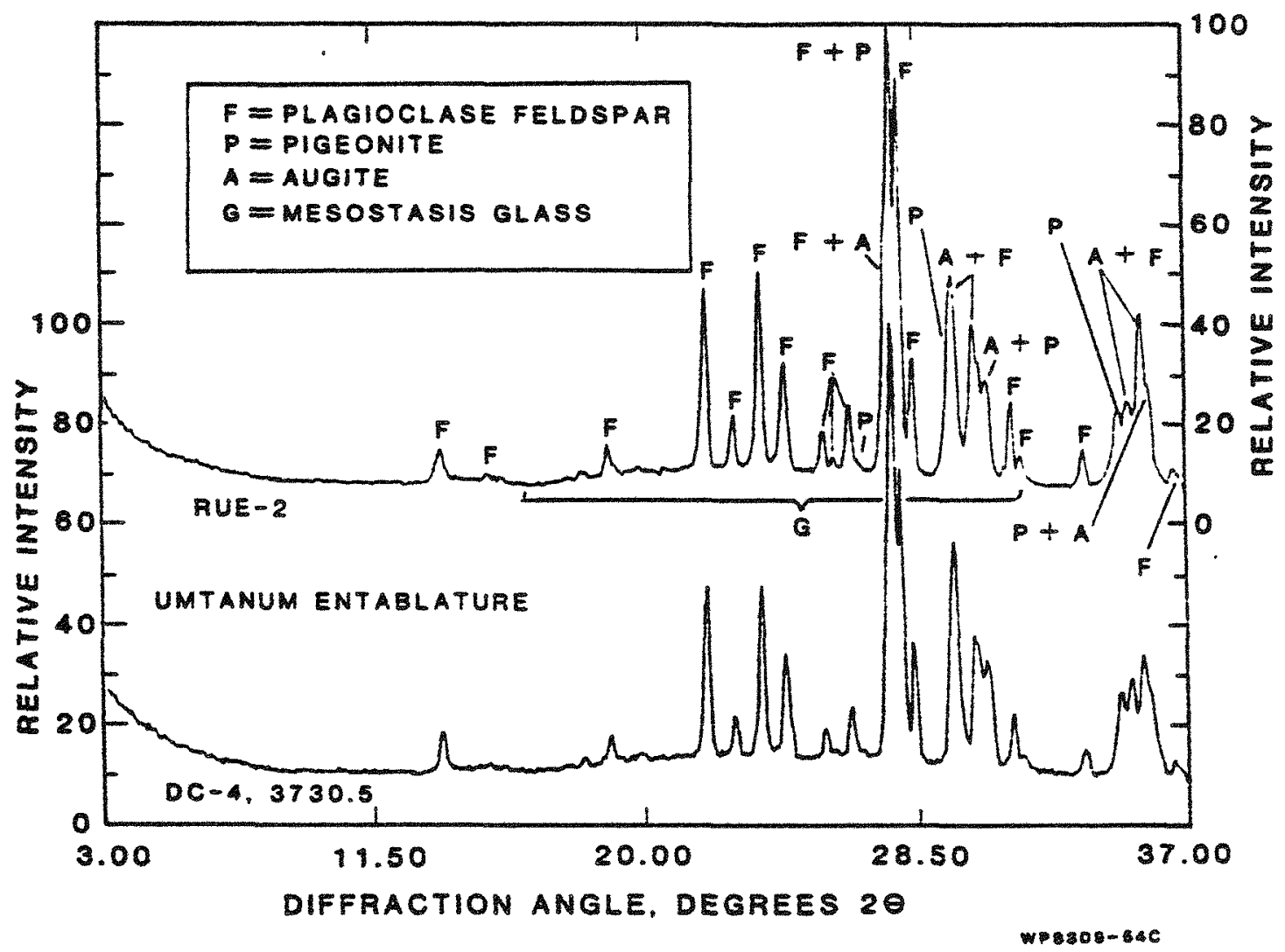

Figure 3. X-ray diffractograms of Umtanum entablature basalt from a surface sample (RUE-2) and a core sample (DC-4, 3730.5). A11 diffractograms were produced from randomly-oriented powder mounts, using copper $K_{\alpha}$ radiation. 
could not be confirmed by XRD. The weak, very broad humps seen in the background of the diffractograms are a product of the mesostasis glass. No evidence of alteration products (clays) was observed in these diffractograms. Petrographic data indicate that these phases are present in quantities too small for detection by bulk XRD.

The major difference between the Umtanum entablature core and surface samples which is apparent in the diffractograms is in the relative abundance of the pyroxenes (see Figure 3). The core sample contains a larger amount of pigeonite relative to augite than does the surface sample. This variation is consistent with observations by Al len and Strope (1983, p. 2), indicating that pigeonite abundance varies significantly in entablature samples. The dfffractograms of the two surface samples. RUE-1 and RUE-2, are nearly identical except for the peak at $3.5^{\circ} 2 \theta$ (Figure 4). This peak is possibly produced by a clay, although no other clay lines ara apparent in the pattern.

$X-r a y$ Flourescence Data

Several size fractions of material are used in repository experiments. There has been some question as to whether or not the processing of the bulk materlal by grinding and sieving has selectively fractionated some of the basalt minerals. To demonstrate that this type of artifact was not being produced. XRF analyses of the largest fraction (-16 +60 mesh) were compared with that of the fraction usualiy involved in testing $(-120+230$ mesh). These results are presented in Table 4 and show that no significant bias is introduced. These data compare closely to XRF analyses of bulk samples from the RUE surface exposure and core (Table 5).

Surface Area

Salter et a1. (1981) used the ethylane glycol absorption method to determine the surface area of a sample of Umtanum basalt sized from 030 to $0.85 \mathrm{~mm}$. The $v a l$ ue reported was $17.7 \pm 3.8 \mathrm{~m}^{2} / \mathrm{g}$. 


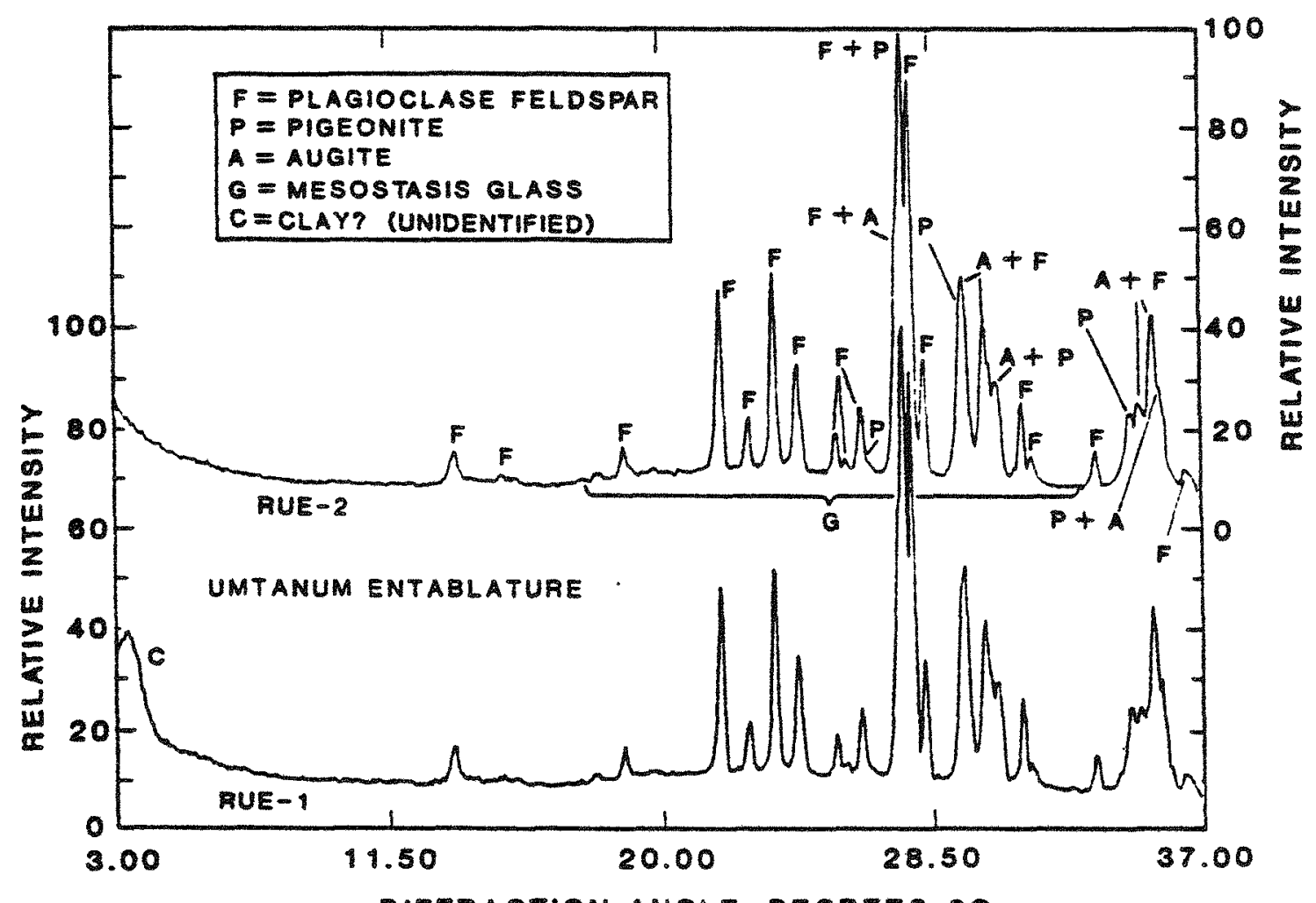

DIFFRACTION ANGLE, DEGREES $2 \theta$

Figure 4. X-ray diffractograms of Umtanum entablature basalt from surface samples RUE-1 and RUE-2, both in $-120+230$ mesh size fractions. The clay peak (C) observed in the RUE-1 specimen is consistent with the alteration products phase reported in point count results from other RUE-1 samples (Table 1). 
$S D-B W I-D P=053$

REV 0

Tabie 4. Normalized Bulk Analysis* of RUE-1 By XRF (wt\%).

\begin{tabular}{|c|c|c|}
\hline & $\begin{array}{c}\text { RUE-1 } \\
-120+230 \text { Mesh }\end{array}$ & $\begin{array}{c}\text { RUE-1 } \\
-16+60 \text { mesh }\end{array}$ \\
\hline$\overline{510_{2}}$ & 54.54 & 54.93 \\
\hline $\mathrm{TiO}_{2}$ & 2.17 & 2.20 \\
\hline $\mathrm{Al}_{2} \mathrm{O}_{3}$ & 15.20 & 14.78 \\
\hline $\mathrm{Fe}_{2} \mathrm{O}_{3}$ ** & 2.00 & 2.00 \\
\hline $\mathrm{F} \otimes 0$ & 10.64 & 10.94 \\
\hline MnO & 0.24 & 0.21 \\
\hline MgO & 3.75 & 3.50 \\
\hline $\mathrm{CaO}$ & 7.07 & 6.98 \\
\hline $\mathrm{Na}_{2} \mathrm{O}$ & 2.45 & 2.50 \\
\hline $\mathrm{K}_{2} \mathrm{O}$ & 1.59 & 1.61 \\
\hline $\mathrm{P}_{2} \mathrm{O}_{5}$ & 0.35 & 0.35 \\
\hline Total & 100.00 & 100.00 \\
\hline
\end{tabular}

* Data from Paimer, et al., 1982, Table 4. * $\mathrm{Fe}_{2} \mathrm{O}_{3}$ arbitrarily set equal to 2.00 . 
SD-BWI-DP-0 053

REV 0

Table 5. Normalized Bulk Analyses by XRF of Umtanum Basalt from Surface Exposures and Core (wt\%)

\begin{tabular}{|c|c|c|c|}
\hline & $\begin{array}{l}\text { Surface } \\
\text { entablature and colonnade }\end{array}$ & $\begin{array}{l}\text { Core } \\
\text { entabiature }\end{array}$ & $\begin{array}{l}\text { Core } \\
\text { colonnade }\end{array}$ \\
\hline $\mathrm{SiO}_{2}$ & 54.60 & 54.88 & 54.73 \\
\hline $\mathrm{T} \mathrm{O}_{2}$ & 2.17 & 2.13 & 2.17 \\
\hline $\mathrm{Al}_{2} \mathrm{O}_{3}$ & 14.77 & 14.28 & 14.65 \\
\hline $\mathrm{Fe}_{2} \mathrm{O}_{3} \mathrm{~d}$ & 2.00 & 2.00 & 2.00 \\
\hline $\mathrm{FeO}$ & 10.79 & 11.08 & 10.86 \\
\hline MnO & 0.22 & 0.22 & 0.22 \\
\hline MgO & 3.42 & 3.44 & 3.39 \\
\hline $\mathrm{CaO}$ & 7.21 & 7.30 & 7.23 \\
\hline $\mathrm{Na}_{2} \mathrm{O}$ & 2.57 & 2.70 & 2.77 \\
\hline $\mathrm{K}_{2} \mathrm{O}$ & 1.81 & 1.62 & 1.52 \\
\hline$P_{2} O_{5}$ & 0.36 & 0.35 & 0.36 \\
\hline Total & 100.02 & 100.00 & 100.00 \\
\hline $\begin{array}{l}a_{\text {Myers }} \\
b_{D C-2,} \\
{ }^{C_{D C}-4}\end{array}$ & $\begin{array}{l}\text { 1. (1979), Plate III-3a. } \\
\text { 4. } \\
\text { 1.3. }\end{array}$ & & \\
\hline
\end{tabular}


Surmary

The RUE basalt consists of glassy mesostasis, plagicelase, pyroxene, titaniferous magnetite, and minor clay. Comparisons of surface and core samples indicate that the RUE material should serve in gecchemical studies as an adequate substitute for material from the proposed repository depth.

\section{Reference Umtanum Colonnade Basait}

Anaysis of reference Untanum colonnade (RUC) samples employed some of the techniques 1 isted above. A single sampling trip yielded reference sample RUC-1 (Noonan et al.. 1981. p. 52). In addition, earlier sampling of the same horizon near the reference site yielded samples C 8098, C 8099 and C 8100 (Myers et a1.. 1979. Plate III-3a).

Petrographic and Microprobe Analysis

Basalt from the RUC horizon contains the same major minerals as the RUE basalt (Tables 6 and 7 ). The colonnade samples are more coarsely crystalline and contain signiflcantly more plagioclase and less mesostasis than does RUE-1. Comparison of Table 7 with Table 2 indicates that the colonnade and entablature plagioclase compositions are essentially identical. These tables also show that the colonnade augite contains more Mgo, and the pigeonite less $\mathrm{MgO}$, than do the respective entablature crystals.

The average composition of RUC-I mesostasis is listed in Table 8. Compariscn with the RUE-I mesostasis (see Table 3 ) indicates that the mesostasis in the Umtanum colonnade is more "evolved" (f.e.s silicon-rich) than that in the entablature, and is similar to that seen in the cohassett colonnade samples (below).

$X-$ ray Diffraction

Characterization of the Umtanum colonnade basalt by X-ray diffraction has been relativeiy limited. Analyses of dffferent size fractions of crushed and blended basalt from the surface sample (RUC-1) produce diffractograms 
SD-BWI-DP-053

REV 0

Table 6. Point Count Data* (modal $\%$ ) for the Reference Untanum Colonnade Horizon (Samples C 8098, C 8099, C 8100).

\begin{tabular}{lccc} 
& C 8098 & C 8099 & C 8100 \\
\hline Plagioclase & 34.8 & 38.0 & 35.9 \\
Pyroxene & 19.2 & 16.5 & 18.6 \\
Mesostasis & 38.2 & 38.5 & 37.9 \\
Titaniferous magnetite & 5.23 & 4.75 & 4.88 \\
Apatite & -0.95 & 1.00 & 0.98 \\
Alteration products & 0.48 & 0.03 & 0.43 \\
Total & 98.9 & 98.8 & 98.7 \\
\hline & 4.000 & 4.000 & 4.000
\end{tabular}

* Analyses by K. R. Falrehilo 
Table 7. Composition of Major Sllicate Minerals* in the Untanum Colonnade (wto).

\begin{tabular}{|c|c|c|c|c|c|c|}
\hline \multirow{2}{*}{ Oxide } & \multicolumn{2}{|c|}{ Plagloclase } & \multicolumn{2}{|c|}{ Pigeonite } & \multicolumn{2}{|c|}{ Augite } \\
\hline & RUC-I & $D C-2,3159$ & RUC-1 & $D C-2,3159$ & RUC-1 & $D C-2,3159$ \\
\hline $\mathrm{SIO}_{2}$ & 56.3 & 57.3 & 50.8 & 51.4 & 50.1 & 49.8 \\
\hline $\mathrm{TIO}_{2}$ & 0.11 & 0.09 & 0.57 & 0.52 & 1.05 & 0.94 \\
\hline $\mathrm{A}_{2} \mathrm{O}_{3}$ & 27.0 & 25.5 & 0.90 & 0.80 & 2.53 & 1.71 \\
\hline $\mathrm{FeO}^{\mathrm{a}}$ & 0.79 & 0.84 & 24.5 & 21.7 & 15.6 & 25.2 \\
\hline Mno & $N D^{b}$ & ND & 0.67 & 0.50 & 0.36 & 0.39 \\
\hline MgO & 0.09 & 0.05 & 17.8 & 20.4 & 15.5 & 14.8 \\
\hline $\mathrm{CaO}$ & 9.4 & 9.4 & 5.91 & 4.81 & 15.3 & 15.0 \\
\hline $\mathrm{Na}_{2} \mathrm{O}$ & 5.3 & 5.1 & 0.07 & 0.09 & 0.27 & 0.23 \\
\hline $\mathrm{K}_{2} \mathrm{O}$ & 0.69 & 0.78 & ND & ND & ND & ND \\
\hline $\mathrm{P}_{2} \mathrm{O}_{5}$ & ND & ND & ND & ND & ND & ND \\
\hline $\mathrm{Cr}_{2} \mathrm{O}_{3}$ & ND & NO & $<0.05$ & $<0.05$ & $<0.05$ & $<0.05$ \\
\hline Total & 99.7 & 100.2 & 101.2 & 100.2 & 200.7 & 99.0 \\
\hline moi & $\begin{array}{l}\text { An } 49 \\
\text { Ab47 } \\
\text { Or } 4\end{array}$ & $\begin{array}{l}\text { An50 } \\
\text { Ab } 45 \\
\text { Or5 }\end{array}$ & $\begin{array}{l}\text { En50 } \\
\text { Fs38 } \\
\text { WoI2 }\end{array}$ & $\begin{array}{l}\text { En57 } \\
\text { F534 } \\
\text { Wo } 9\end{array}$ & $\begin{array}{l}\text { En } 44 \\
F s 25 \\
\text { Wo31 }\end{array}$ & $\begin{array}{l}\text { En } 4 \\
\text { Fs26 } \\
\text { Wo31 }\end{array}$ \\
\hline
\end{tabular}

* Microprobe data from Noonan, et al.. 1981. Table 1.

Ail iron reported as FoO.

$b_{\text {ND }}=$ Not jetected. 
Table 8. Composition of Mesostasis* in the Umtanum Colonnade (wt\%). a

\begin{tabular}{|c|c|c|}
\hline Oxide & $R U C-I$ & $D C-2,3159$ \\
\hline $\mathrm{SiO}_{2}$ & 72.2 & 72.9 \\
\hline $\mathrm{T}^{1 \mathrm{O}_{2}}$ & 0.69 & 0.88 \\
\hline $\mathrm{A}_{2} \mathrm{O}_{3}$ & 12.5 & 12.7 \\
\hline $\mathrm{FeO}^{\mathrm{b}}$ & 1.59 & 2.16 \\
\hline Mno & $<0.05$ & $<0.05$ \\
\hline Mgo & $<0.05$ & $N D^{C}$ \\
\hline $\mathrm{CaO}$ & 0.51 & 0.62 \\
\hline $\mathrm{Na}_{2} \mathrm{O}$ & 4.01 & 6.6 \\
\hline $\mathrm{K}_{2}{ }^{\mathrm{O}}$ & 6.5 & 4.07 \\
\hline $\mathrm{P}_{2} \mathrm{O}_{5}$ & 0.12 & 0.10 \\
\hline $\mathrm{Cr}_{2} \mathrm{O}_{3}$ & ND & ND \\
\hline Total & 98.1 & 100.0 \\
\hline
\end{tabular}

* Microprobe data from Noonan et al., 1981, Table 3.

Average of seven analyses.

ball iron reported as FeO

$C_{\text {ND }}=$ Not Detected. 
SD-BWI-DP-053

REV 0

wich are very similar to patterns which characterize samples of the Umtanum entablature (Figure 5). The plagioclase patterns are nearly identical, and support microprobe evidence of the essentially identical plagioclase chemistries in both colonnade and entablature. The pyroxene diffraction ines are less similar, with the pigeonite pattern more clarly resolved in the colonnade. The pyroxenes appear to be similar to those present in the entablature, ylelding diffraction patterns which alsc match the reference diffractograms. As in the entablature, no X-ray diffraction evidence of alteration products (clay) was observed, and the presence of titanfferous magnetite could not be confirmed. The broad background hump indicative of mesostasis glass is less intense in the colonnade diffractogram than in that of the entablature, suggesting that a smal ler amount of noncrystal I ine material is present.

The diffractogram of the Untanum colonnade core specimen differs somewhat from surface colonnade material (Figure 6). The core sample diffractogram suggests that small amounts of potassium feldspar and cristobalite may be present in the specimen. Differences in the relative abundances of augite and pigeonite, and possibly in the composition of the pigeonite (see Table 7) are implied by intensity and shape changes of the pyroxene peaks. The pyroxene peaks are particularly well resolved in this sample, especialiy at higher diffraction angles.

$x$-ray Fluorescence

The bulk chemical composition of Umtanum colonnade basalt, as determined by XRF, is given in Table 5. No significant differences exist between the bulk composftions of colonnade and entablature samples, nor between samples collected at the surface and from deep drill cores.

Summary

The reference Umtanum colonnade basalt, based on I imited characterization, resembies the reference Untanum entablature material in terms of bulk chemical composition and mineralogy. However, the major minerals and, to a greater extent, the mesostasis differ significantiy in chemical composition. 


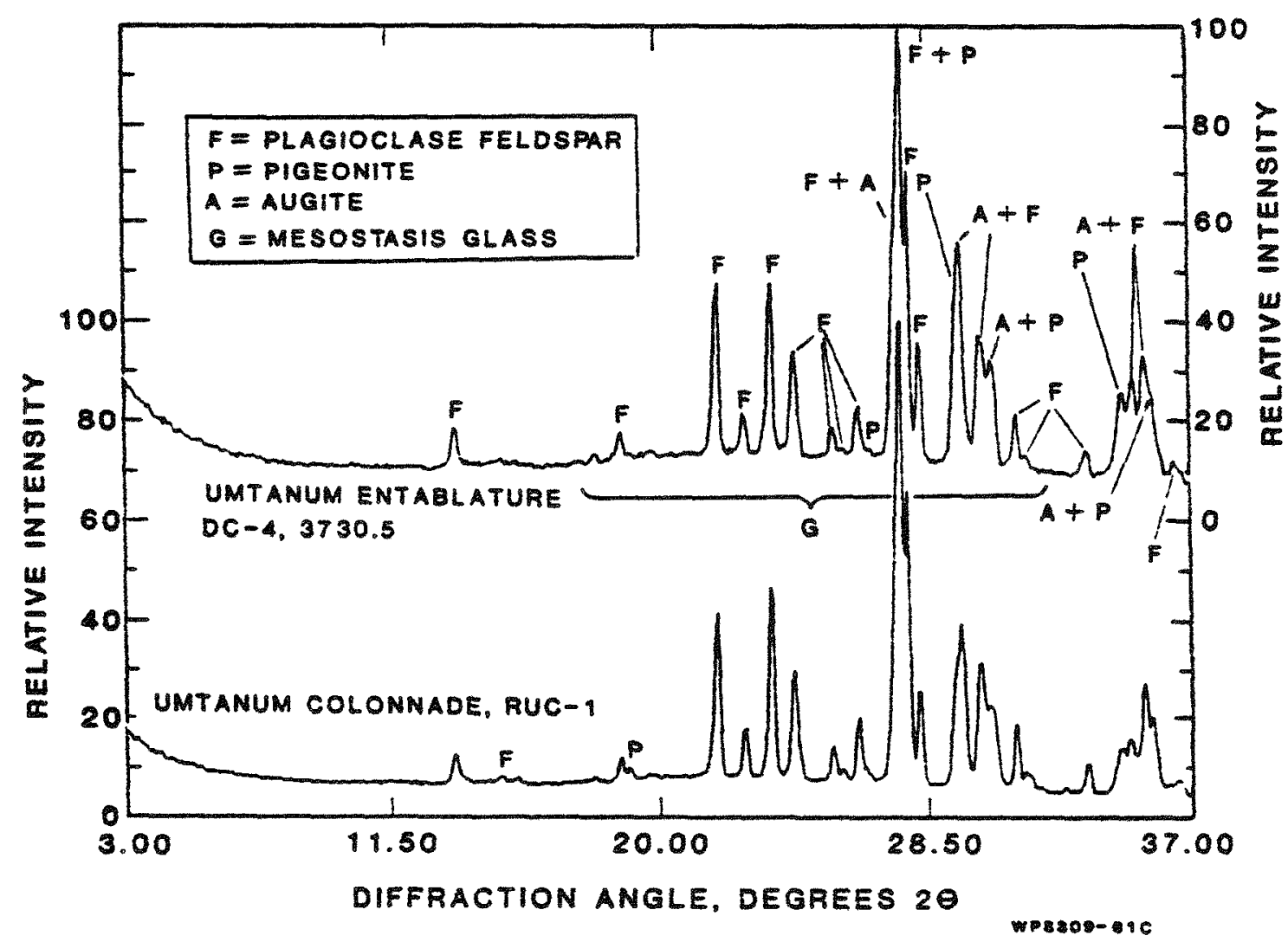

Figure 5. Comparison of $X$-ray diffractograms from the Umtanum entablature and colonnade. 


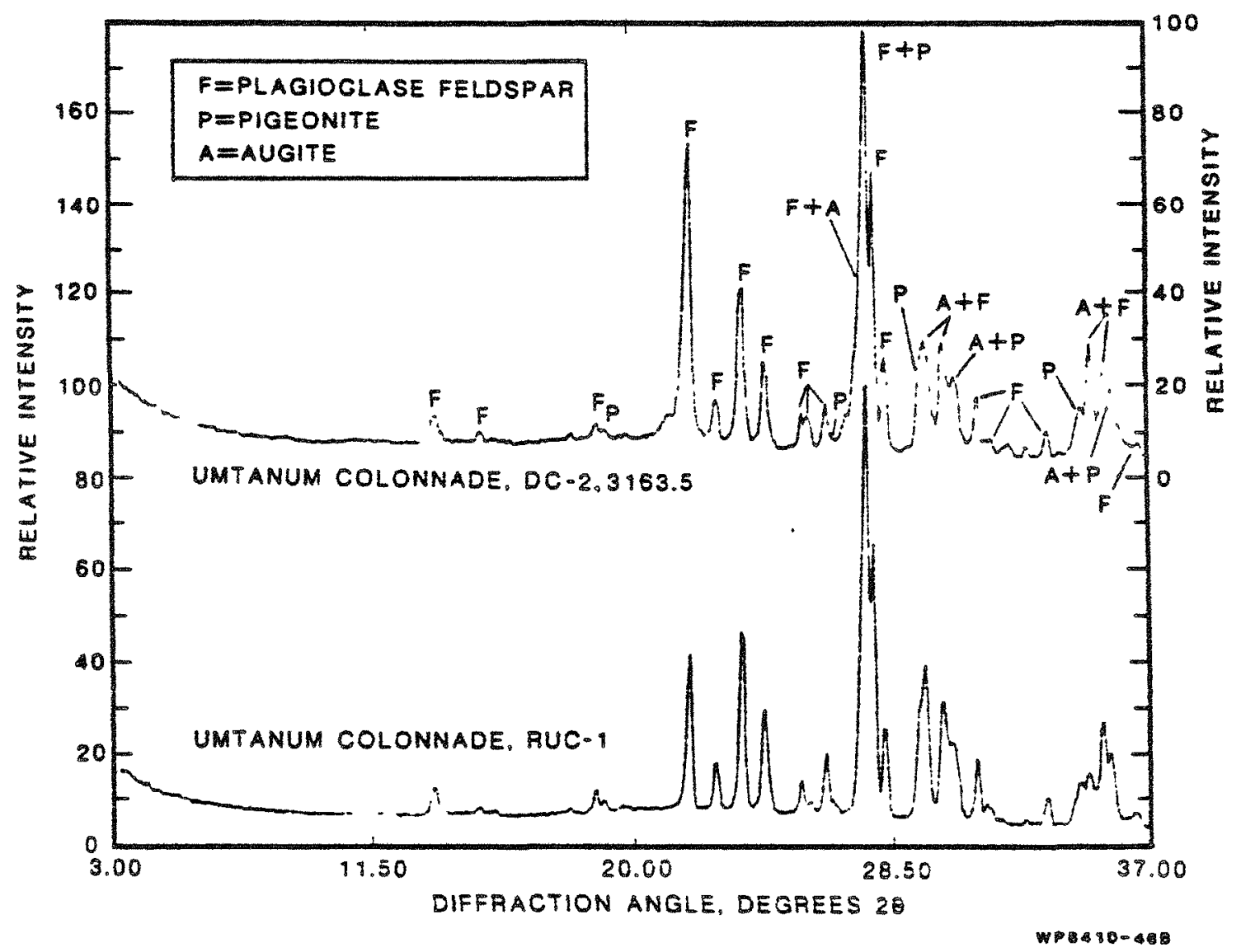

Figure 6. X-ray diffractograms of core $(D C-2,3163.5)$ and surface (RUC-1) samples of Umtanum colonnade. 
Reference surface samples are very simflar to core samples from the same horizon.

\section{Reference Cohassett Entablature Basalt}

Analysis of reference Cohassett entablature (RCE) samples employed the suite of techniques 1 isted above. As of this report, four sampling trips had produced reference materlal designated RCE-1, RCE-2, RCE-3 and RCE-4. In addition. previous sampling of the same horizon in the near vicinity of the reference site yielded samples C 9015 and C 9016 (Myers et a 1., 1979. Plate III-3b).

Petrographic and Microprobe Analysis

The RCE basalt is grossiy similar to the Umtanum entablature material described above. The dominant phases are plagioclase, augite, pigeonite, dendritic titaniferous magnetite, and mesostasis (Tables 9, 10). The mean dimensions of the plagloclase and pyroxene crystals, however, are characteristically 2 to 5 times larger in Cohassett basalt than in Umtanum samples. In addition, Cohassett samples contain significantly larger volumes of alteration products, mainly elay, than do Untanum samples. The texture cf a typical section of RCE-1 is shown in Figure 7 .

Mescstasis, as defined by point counting, comprises approximately 30 modal $\%$ of the basalt from the RCE horizon (see Table 9). Over half of this amount is opticality amorphous slifica-rich glass (Table 11). The remainder. (Figure 8) consfsts of micron-scalo plagioclase crystals and microcrystalline blebs containing pyroxene, magnetite, and apatite (Allen and Strope, 1983. p.2).

X-ray Diffraction

$X$-ray diffractograms of Cohassett entablature basalt from a core sample (RRL-2, 3i34) and from a surface sample (RCE-1) are compared in figure 9. Plagioclase feldspar is the most abundant phase in the basalt, as indicated by the relative intensities of its major diffraction peaks. The plagioclase 
SD-BWI-DP-0 53

REV 0

Table 9. Point Count Data* (modal $\%$ ) for the Reference Cohassett Entablature Horizon (Samples C 9015, C 9016).

\begin{tabular}{lcc}
\hline & C 9015 & C 9016 \\
\hline $\begin{array}{lll}\text { Plagloclase } \\
\text { Pyroxene }\end{array}$ & 36.5 & 37.3 \\
$\begin{array}{l}\text { Mesostasfs } \\
\text { Titanfferous }\end{array}$ & 20.6 & 21.0 \\
magnetite & 30.5 & 32.5 \\
Apatite & 3.70 & 4.60 \\
$\begin{array}{l}\text { Alteration } \\
\text { Products }\end{array}$ & TRACE & TRACE \\
\hline Total & 8.30 & 5.03 \\
\hline Polnts counted & 4.000 & 100.4 \\
\hline
\end{tabular}

* Analyses by K. R. Fairchild 
Table 10. Composition of Major Sillcate Minerals (wtm) from the Reference Cohassett Entablature Horizon (Sample C 9016).

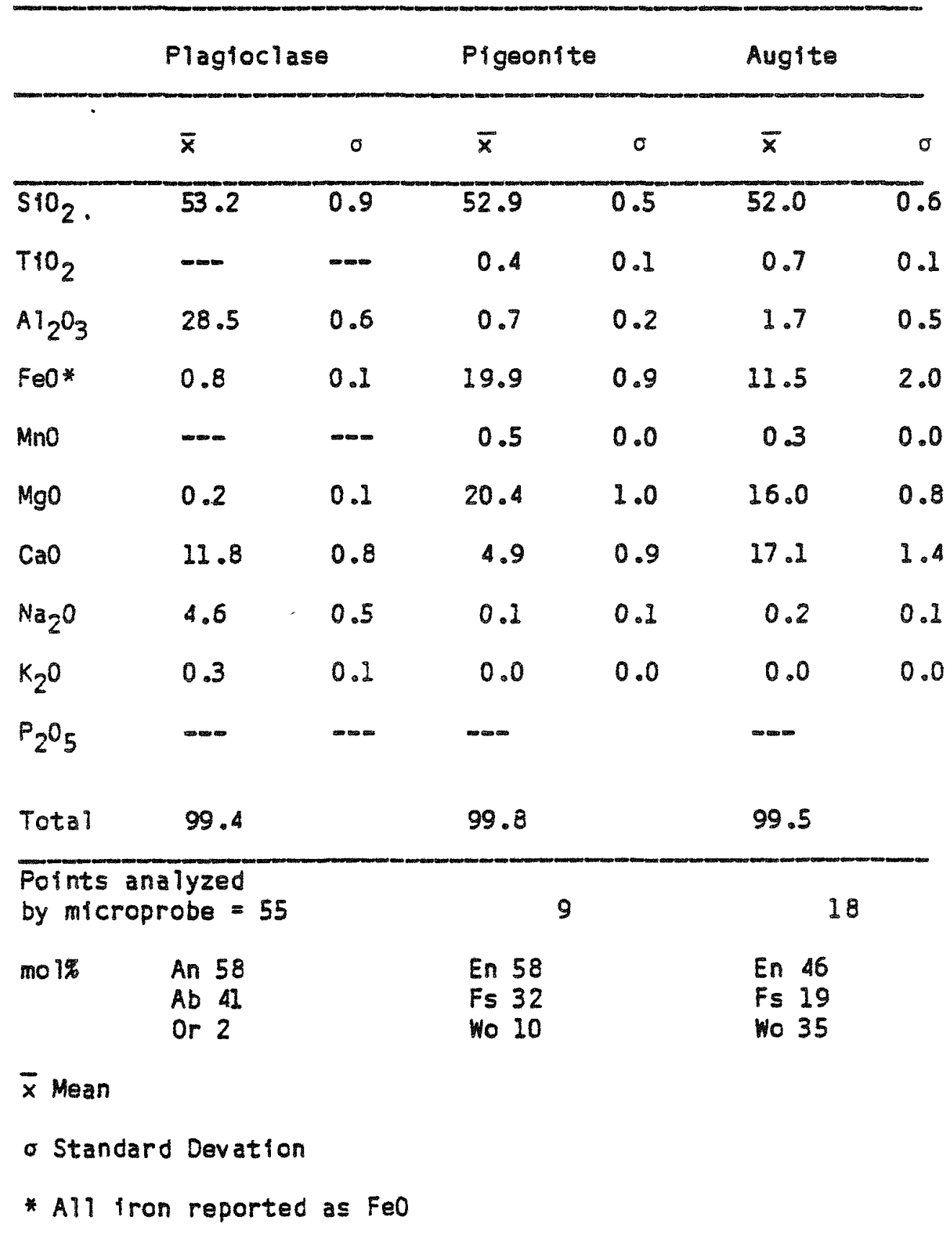




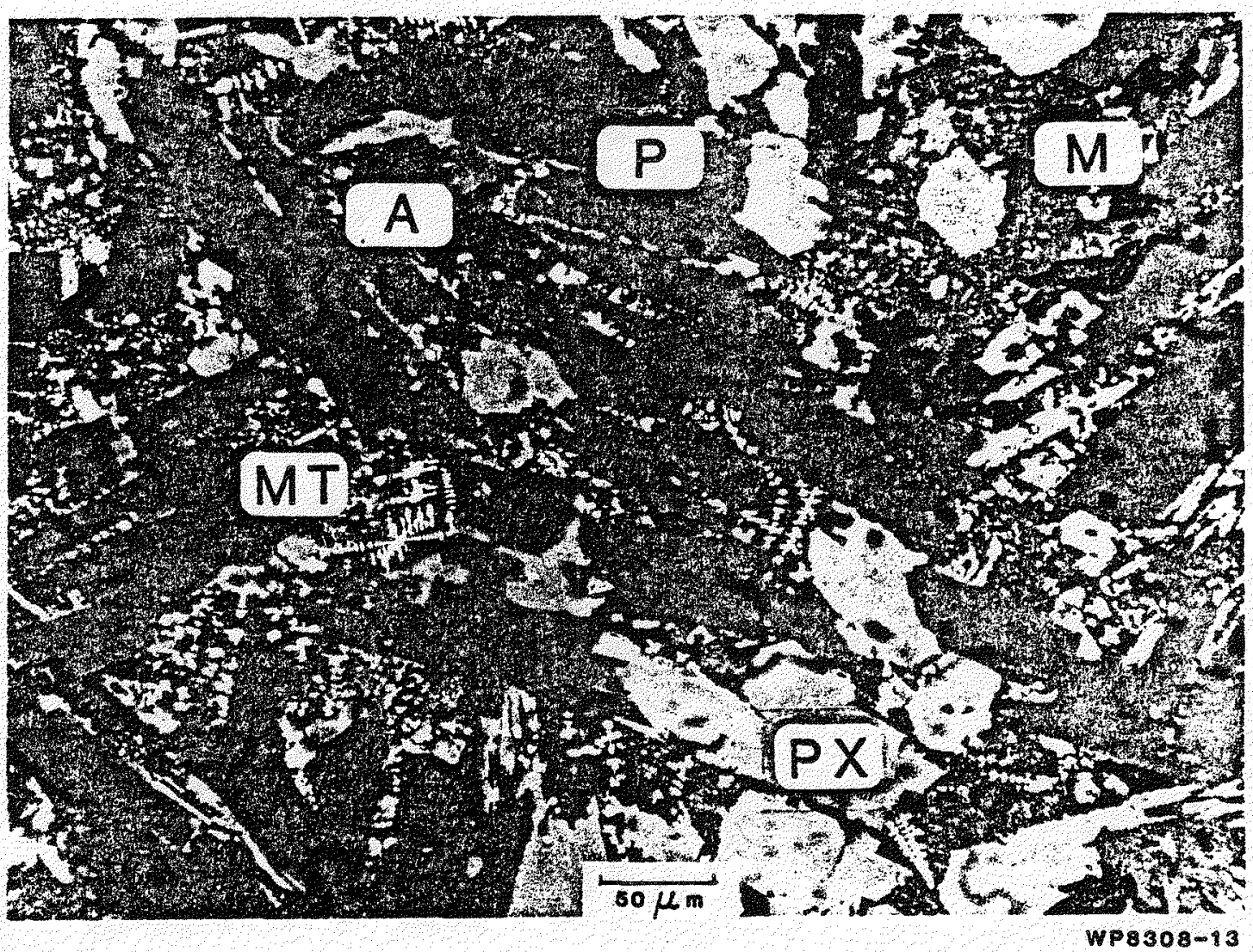

Figure 7. Reflected light photomicrograph of RCE-1 basalt. Plagioclase (P), pyroxene (PX), mesostasis (M), magnetite (MT), alteration (A). 
Tabie 11. Composition of Mesostasis Glass (wt\%) fron the Reference Cohassett Entabiature Horizon (Sample C 9016)

\begin{tabular}{lcc}
\hline & $\bar{x}$ & $\sigma$ \\
\hline $\mathrm{SiO}_{2}$ & 65.1 & 3.2 \\
$\mathrm{TrO}_{2}$ & 1.0 & 0.6 \\
$\mathrm{Al}_{2} \mathrm{O}_{3}$ & 14.0 & 2.1 \\
$\mathrm{FeO}^{*}$ & 5.4 & 2.4 \\
$\mathrm{MnO}$ & 0.4 & 0.1 \\
$\mathrm{MgO}$ & 0.5 & 0.8 \\
$\mathrm{CaO}_{2}$ & 3.1 & 1.4 \\
$\mathrm{Na}_{2} \mathrm{O}$ & 4.2 & 0.9 \\
$\mathrm{~K}_{2} \mathrm{O}$ & 3.4 & 1.0 \\
$\mathrm{P}_{2} \mathrm{O}_{5}$ & 0.6 & 0.2 \\
$\mathrm{Total}$ & 97.7 & \\
\hline
\end{tabular}

Points analyzed by microprobe $=68$

$\bar{x}$ Mean

o Standard Deviation

* All iron reported as FeO 


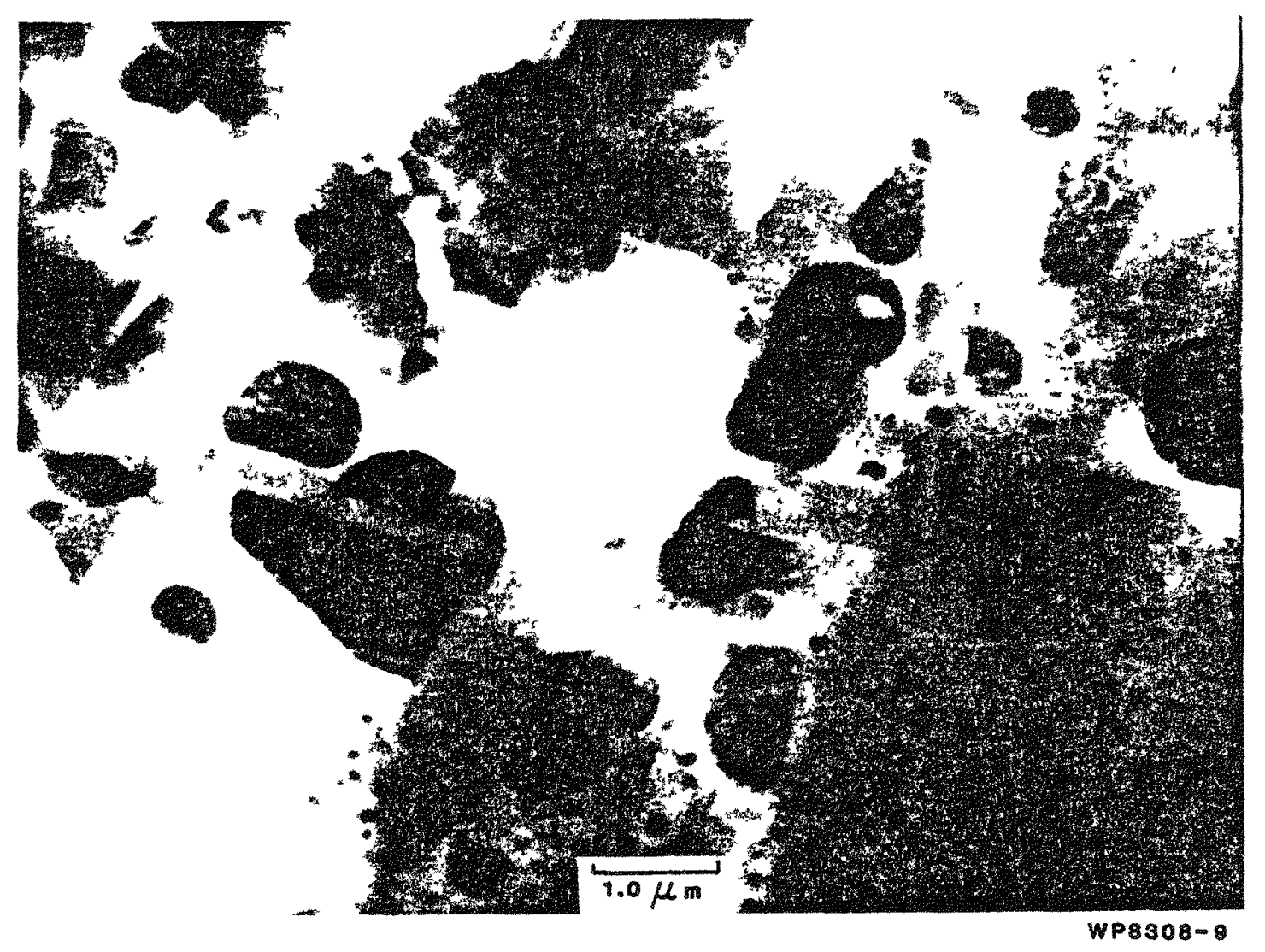

Figure 8. STEM photograph of RCE-1 glass. Lath-shaped crystais are plagioclase. Dark subrounded blebs contain pyroxene, magnetite, and apatite microcrystals. 


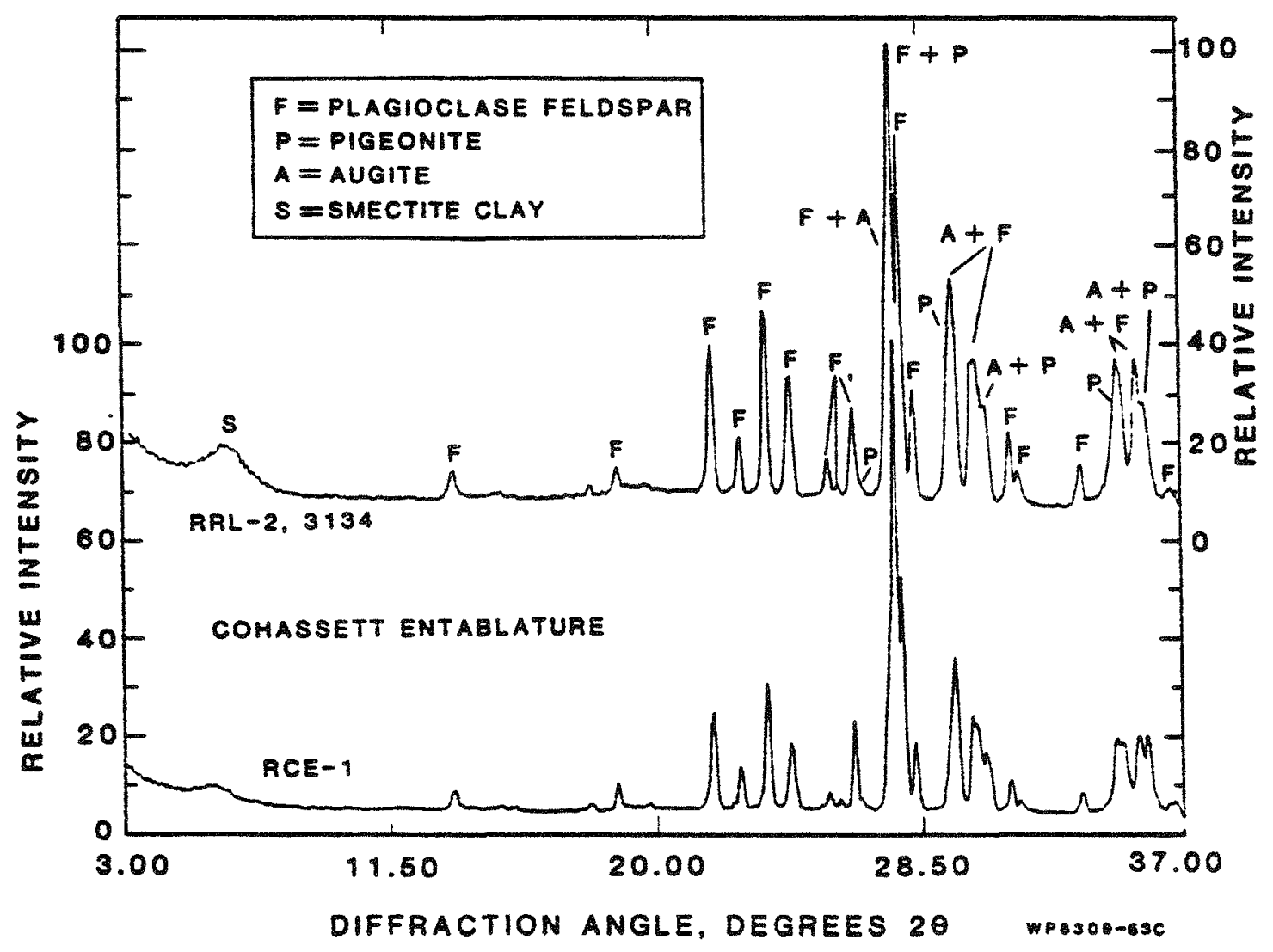

Figure 9. X-ray diffractograms of Cohassett entablature basalt from a core sample (RRL-2, 3134) and a surface sample (RCE-1). 
SD-BWI-DP-0 53

REV 0

diffraction pattern provides good matches ith two PDF patterns (18-1202:

$A n_{67.2}, A b_{31.5}, O r_{135} ; 9-465: A n_{64.5}, A b_{37.2}, O r_{2.8}$, 1 isted as intermediate and low sodian anorthite, respectively. Small differences in the peak positions relative to the reference diffractograms are consistent wth the composition of the plagioclase (more sodic than the reference materials) as determined by electron microprobe. Most of the remainder of the basait diffractogram is accounted for by clinopyroxenes, predominately augite (PDF 24-203), along (th a smaller amount of pigeonite (PDF 13-421). The alteration products observed in the petrographic studies appear in the $X$-ray diffractograms as the third most abundant phase. The single peak, although weak, suggests that the phase is a smectite clay. The titaniferous magnetite observed optically and by SEM imaging could not be identified by XRD, due to the small quantity present and overlaps of the major magnetite dffraction peaks wth those of more abundant phases. Simflarly, the trace quantity of apatite (Table 9) was not observed by XRD. The microcrystalline plagloclase and pyroxenes in the mesostasis contribute to the diffractcgrams produced by theip larger counterparts in the basalt. Indications of the glassy phase, which comprises at least half of the mesostasis and thus around 15 modal of the basalt (see Table 9) are not present in the diffractogram.

As can be seen in Figure 9 , the differences between surface and core samples of the cohassett entablature basalt are relatively minor. Also, the Umtanum and Cohassett entablature basalts are quite similar, as shown in Figure 10. The primary difference occurs in the pyroxenes, relecting the much smaller quantity of pigeonite present in the Cohassett entablature relative to the intanum entablature (Long and Strope, 1983, p. 2). The plagioclase feldspar in the Umtanum entablature samples, based on a comparison of diffraction line positions, is slightly more albitic. This observation is consistent with the composition data for the two basalts.

The evidence for mesostasis giass seen in the diffraction pattern of Umtanum entablature basalt is not seen in the diffractogran of the Cohassett entablature, further evidence of the lesser quantity of mescstasis glass in the Cohassett flow. No smectite was seen in any of the Untanum patterns, although evidence of a different clay phase was occasionaliy present. 


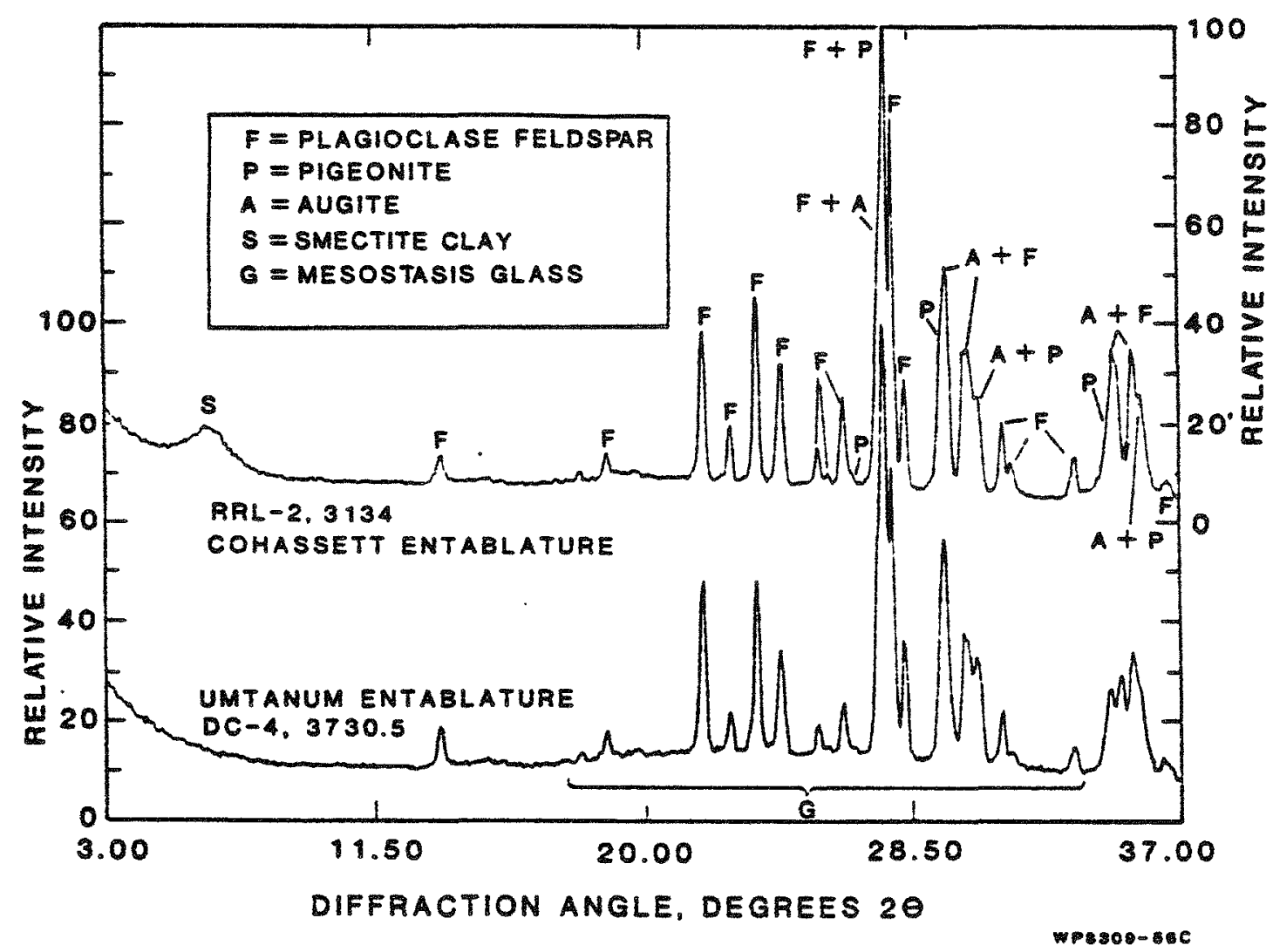

Figure 10. Comparison of X-ray diffractograms from core samples of the Cohassett and Umtanum entablature basalts. Minor differences in the primary mineral compositions are visible. No secondary clay is evident in the diffractogram of the Umtanum sample, and evidence of mesostasis glass is absent from the Cohassett pattern. 
Some minor compositicnal variations are observed by XRD among different samples of the Cohassett entablature. The plagioclase composition varies sightly from sample to sample, as do the relative quantities of augite and pigeonite. These variations produce sight differences in the positions and intensities of the major diffraction paaks of each phase, as shown in a comparison of samples from RCE-1, RCE-2, and RCE-3 in Figure 11. Differences in clay content among the samples are also evident in the diffractograms. Preliminary analysis of RCE-4 indicates that this material has the highest clay content of the four reference Cohassett entablature samples.

$X-$ ray Fluorescence

The bulk chemical compositions of Cohasset surfaces and core samples, as determined by XRF, are presented in Table 12. The bulk compositions of entablature and colennade basalts are essentially identical. In addition. the average surface sample closely resembles those from depth, indicating that weathering has had minimal effect on the bulk composition of cohassett basait.

Summary

The Cohassett entablature, both at the reference surface location and at depth. is generally similar to the Umtanum entablature. Differences in crystal size, degree of alteration, and bulk chemical compesition are considered minor. The reference cohassett entablature material collected at the surface closely resembles Cohassett entablature basalt from the proposed repository depth, and should be an adequate substitute in geochemical tests.

\section{Reference Cohassett Colonnade Basait}

Analysis of reference Cohassett colonnade (RCC) samples employed the suite of techniques listed above. As of this report, three sampling trips had produced reference material designated RCC-1, RCC-2, and RCC-3. In addition, previcus sampling of the same horizon in the near vicinity of the reference site yielded sample C 9017 (Myers et al., 1979, Plate III-36). 


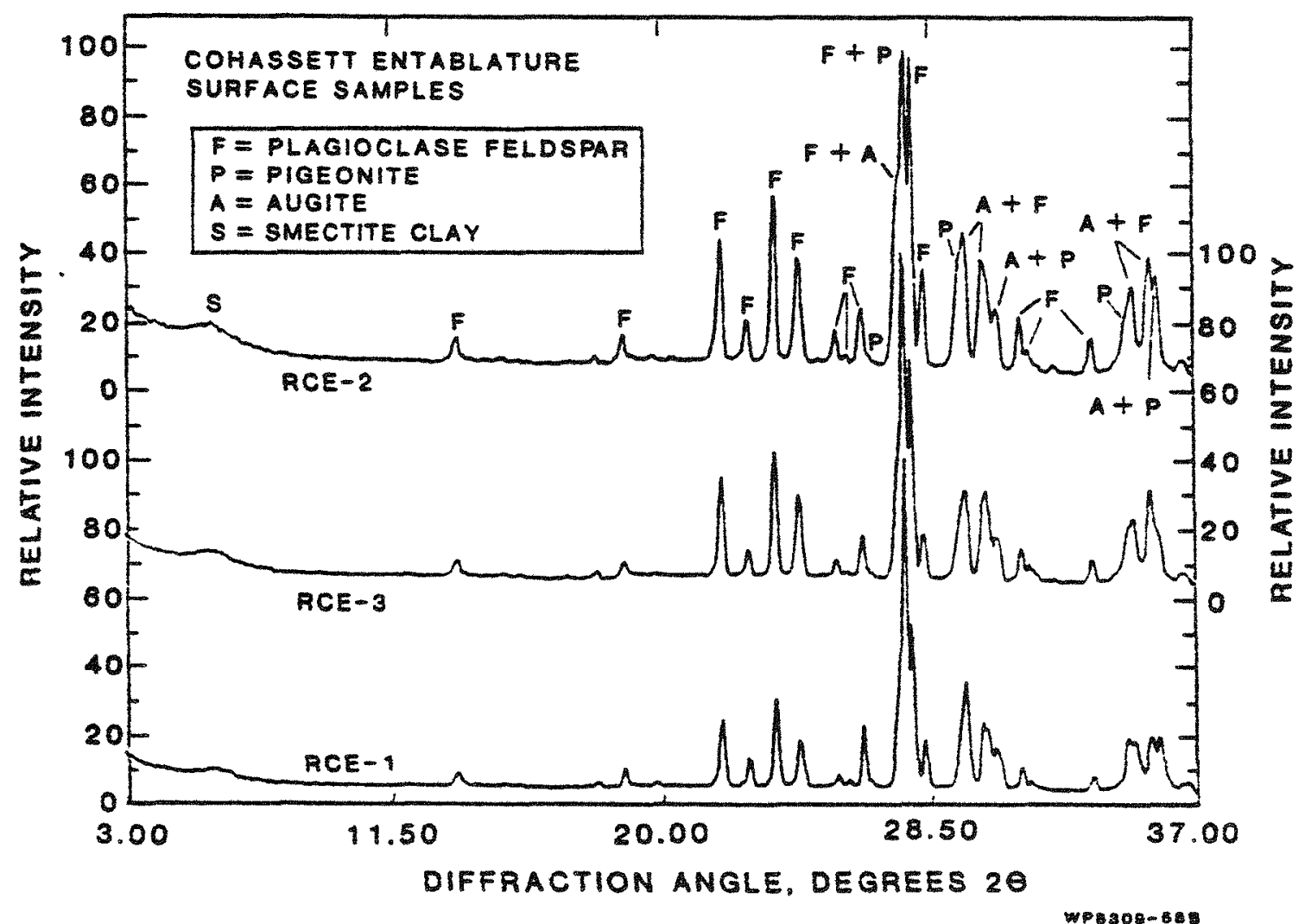

Figure 11. Comparison of X-ray diffractograms from three surface samples of reference Cohassett entablature basalt. 
$S D-B W I-D P-053$

REV 0

Tabie 12. Normalized Bulk Analysis by XRF of Cohassett Basalt from Surface Exposures and Core (wt\%).

\begin{tabular}{|c|c|c|c|}
\hline & $\begin{array}{l}\text { Surface } \\
\text { entabiature plus colonnade }\end{array}$ & $\begin{array}{l}\text { Core } \\
\text { entablature }\end{array}$ & $\begin{array}{l}\text { Core } \\
\text { colonnade }\end{array}$ \\
\hline $\mathrm{SiO}_{2}$ & 53.27 & 52.95 & 53.08 \\
\hline $\mathrm{TrO}_{2}$ & 1.80 & 1.69 & 1.79 \\
\hline $\mathrm{Al}_{2} \mathrm{O}_{3}$ & 14.93 & 15.08 & 15.12 \\
\hline $\mathrm{Fe}_{2} \mathrm{O}_{3}{ }^{d}$ & 2.00 & 2.00 & 2.00 \\
\hline$F_{90}$ & 10.08 & 10.04 & 9.91 \\
\hline Mno & 0.21 & 0.20 & 0.22 \\
\hline $\mathrm{MgO}$ & 4.92 & 5.27 & 5.12 \\
\hline $\mathrm{CaO}$ & 8.90 & 9.03 & 8.93 \\
\hline $\mathrm{Na}_{2} \mathrm{O}$ & 2.46 & 2.55 & 2.47 \\
\hline $\mathrm{K}_{2} \mathrm{O}$ & 1.13 & 0.94 & 1.20 \\
\hline $\mathrm{P}_{2} \mathrm{O}_{5}$ & 0.30 & 0.25 & 0.27 \\
\hline Total & 100.00 & 100.00 & 100.01 \\
\hline
\end{tabular}

ayers et al., 1979, Plate III-3b.

bDC-2, 2556.

CDC-4, 3050.9 .

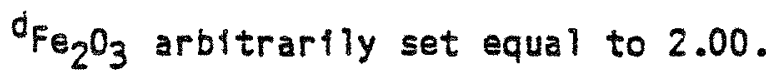


REV 0

Petrographic and Microprobe Analysis

The RCC basalt differs significantly from the entablature samples described above. While the major phases, f.e.s plagloclase, pyroxene, titaniferous magnetite and mesostasis are present (Table 13), their abundances are somewhat different. In general, colonnade basalt contains a higher abundance of crystalline phases and consequentiy, a lower abundance of mesostasis than entablature basalt (compare Tables 9 and 13).

The sizes and morphologies of the minor phases in colonnade and entablature samples are also different, as comparison of figures 12 and 7 indicates. Titanifercus magnetite crystais in cclonnade samples are large and somewhat blocky. In addition, hollow needle-shaped crystals of fluorapatite ith glass-fil led interlors and hexagona? cross-sections (figure 13) constitute approximately I modal of many Cohassett colonnade samples. The colcnnade mesostasis contains very few of the blebs which characterize the entablature mesostasis. Like the entablature basalt, the Cohassett colonnade samples, both at the surface and at depth, contain several percent alteration products, chiefly clay.

The average chemical compositions of plagioclase, pigeonite, and augite crystals in the RCC horizon are 1 isted in Table 14. The plagioclase composition matches that of the Cohassett entablature plagioclase (see Table 10) within one standard deviation. The colonnade augite composition matches that for augite in the Cohassett entablature (Table 10 and Long and Stropes 1983. Table 1). However, the colonnade pigeonite (see Tables 14 and 10 ) is considerably more fe-rich than the entablature pigeonite. Long and Strope (1983, p. 2) also noted that, in the Cohassett flow, the pigeonite/augite ratio is much larger in the colonnade than in the entablature.

The chemical composition of Cohassett colonnade glass, averaged from 58 microprobe point analyses, is listed in Table 15. Scanning electron microscopy indicates that this is actualiy a two-phase glass, containing one phase ith a chemical composition resembling sodium-potassium feldspar and a second phase contalning almost pure sflica (Figure 14). The STEM electron diffraction patterns indicate a low but ldentiflable degree of crystalinity, 
SD-BWI-DP-053

REV 0

Table 13. Pcint Count Data* (Modal 5) for the Reference

Cohassett Colonnade Horlzon (Sample C 9017).

\begin{tabular}{lc}
\hline & $C 9017$ \\
\hline Plagiociase & 43.2 \\
Pyroxene & 24.7 \\
Mesostasis & 22.0 \\
Titanfferous Magnetite & 3.42 \\
Apatite & 0.92 \\
Alteration Products & 5.82 \\
& -100.1 \\
\hline
\end{tabular}

Points Counted $=4,000$

* Analyses by K. R. Fairchild 


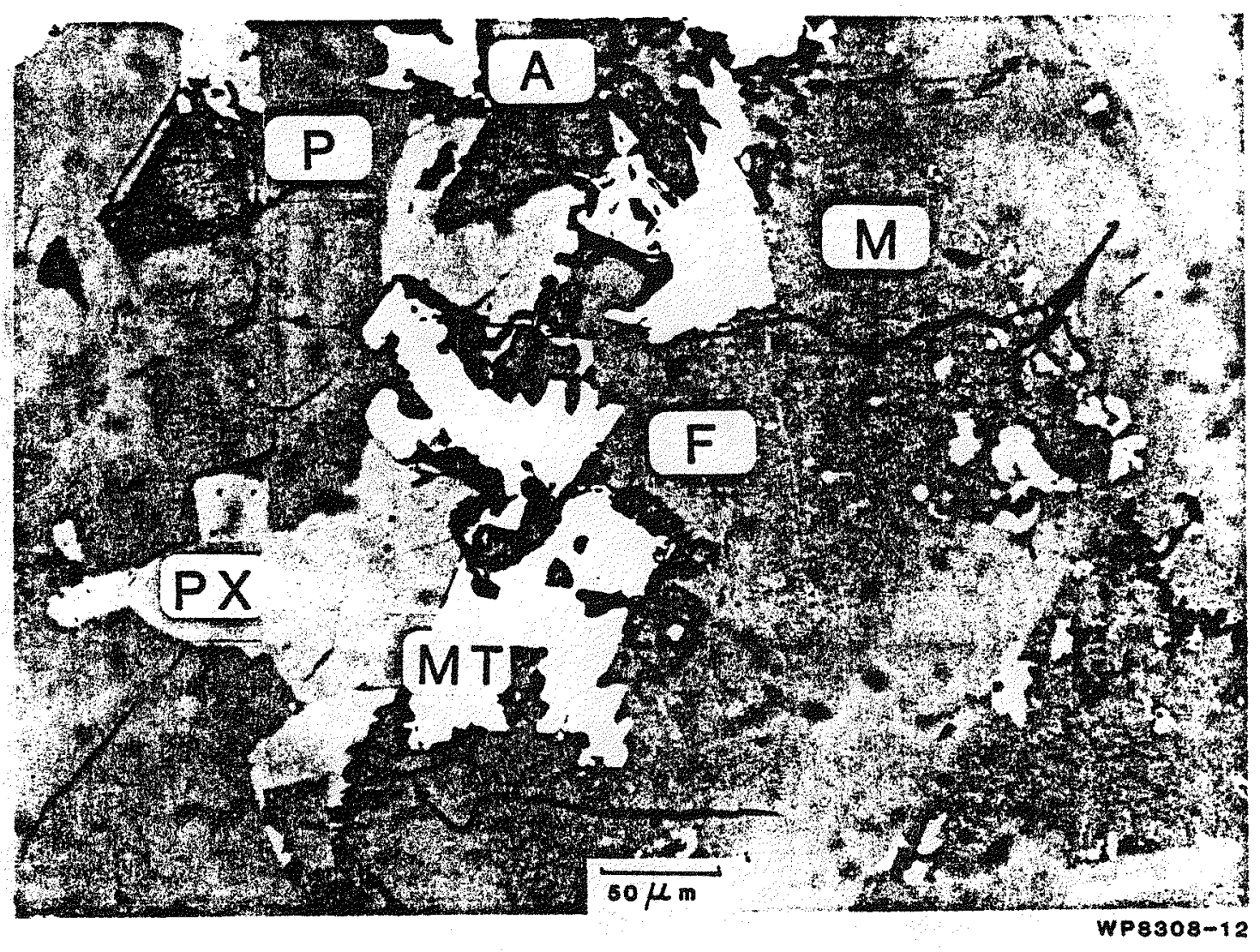

Figure 12. Reflected light photomicrograph of RCC-1 basalt. Plagioclase ( $P)$, pyroxene (PX), mesostasis (M), magnetite (MT), fluorapatite (F), alteration (A). 


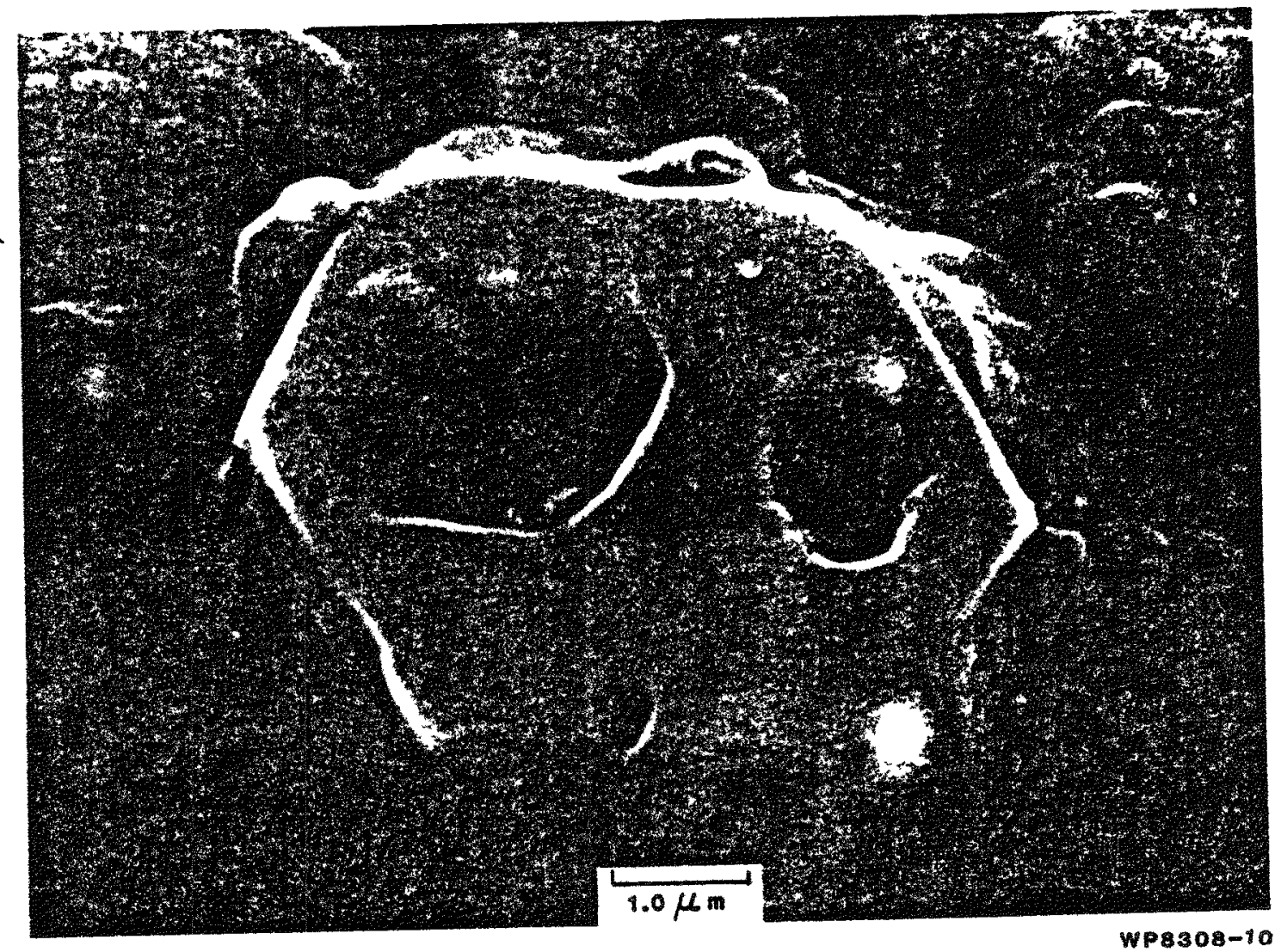

Figure 13. SEM photograph of a fluorapatite crystal, viewed end-on, in RCC-1 basalt. The crystal is hollow and filled with glass. 
SD-BWI-DP-0 53

REV $O$

Table 14. Compositions of Major Sllicate Minerals (wt\%) from the Reference Cohassett

Colonnade Horizon (Sample C 9017)

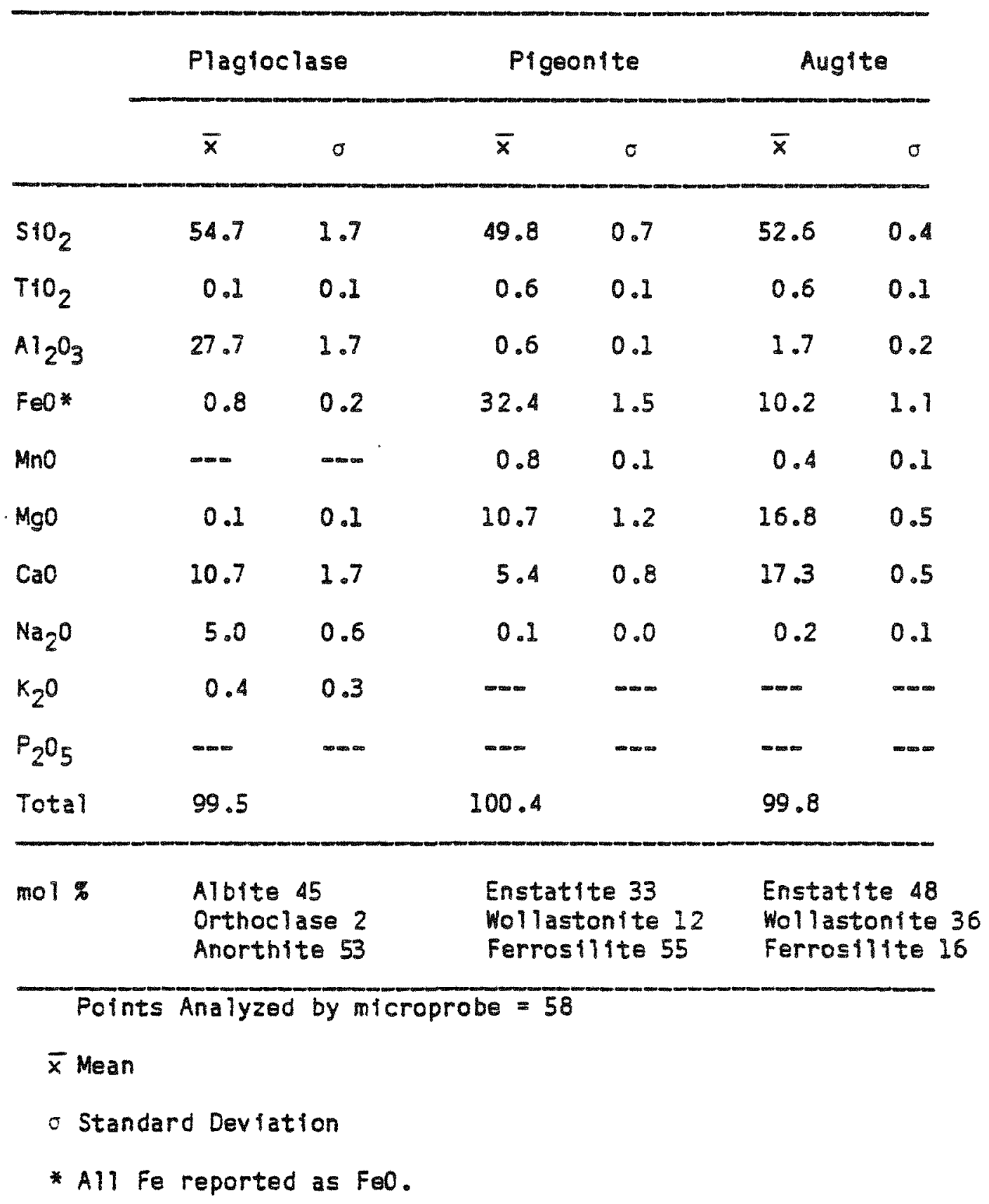


SD-BWI-DP-0 53

REV 0

Tabie 15. Composition of Mesostasis Glass (wt\%) from the Reference Cohassett Colonnade Horizon

(Sample C 9017).

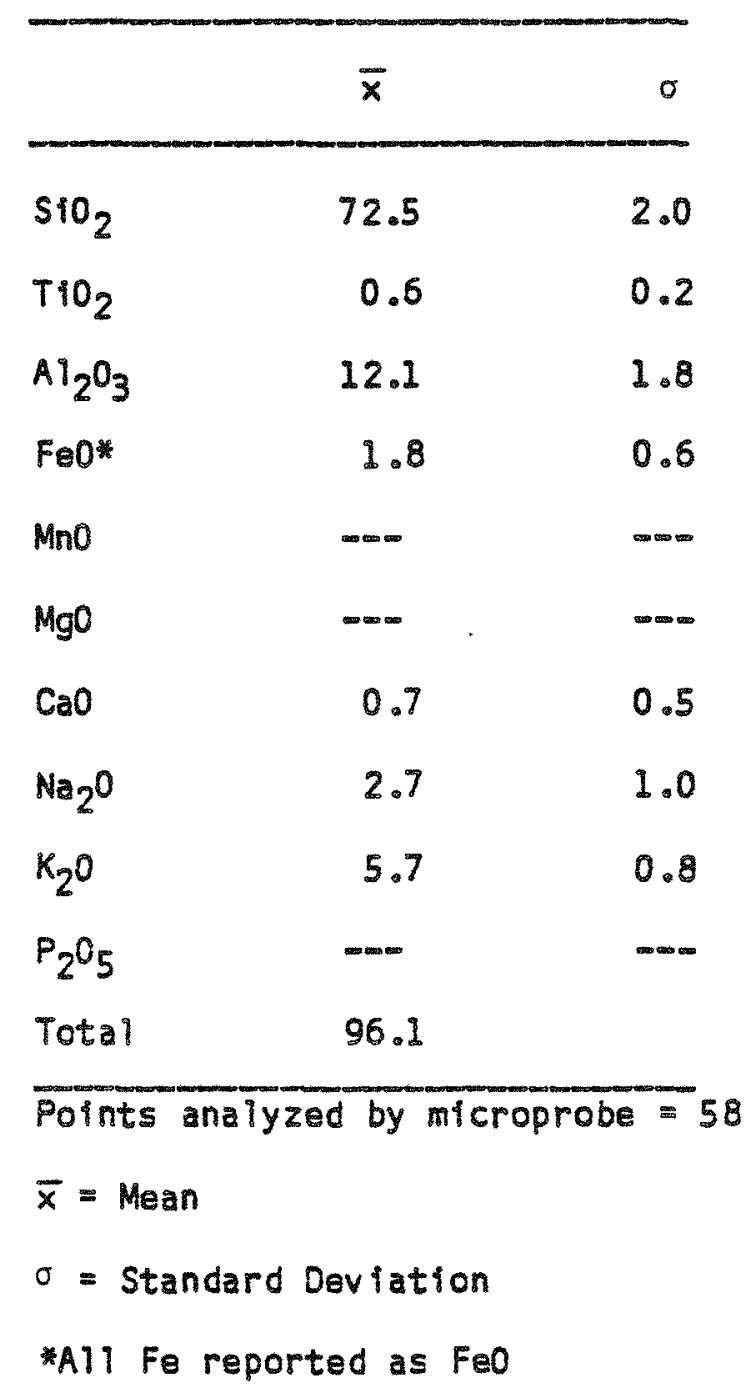



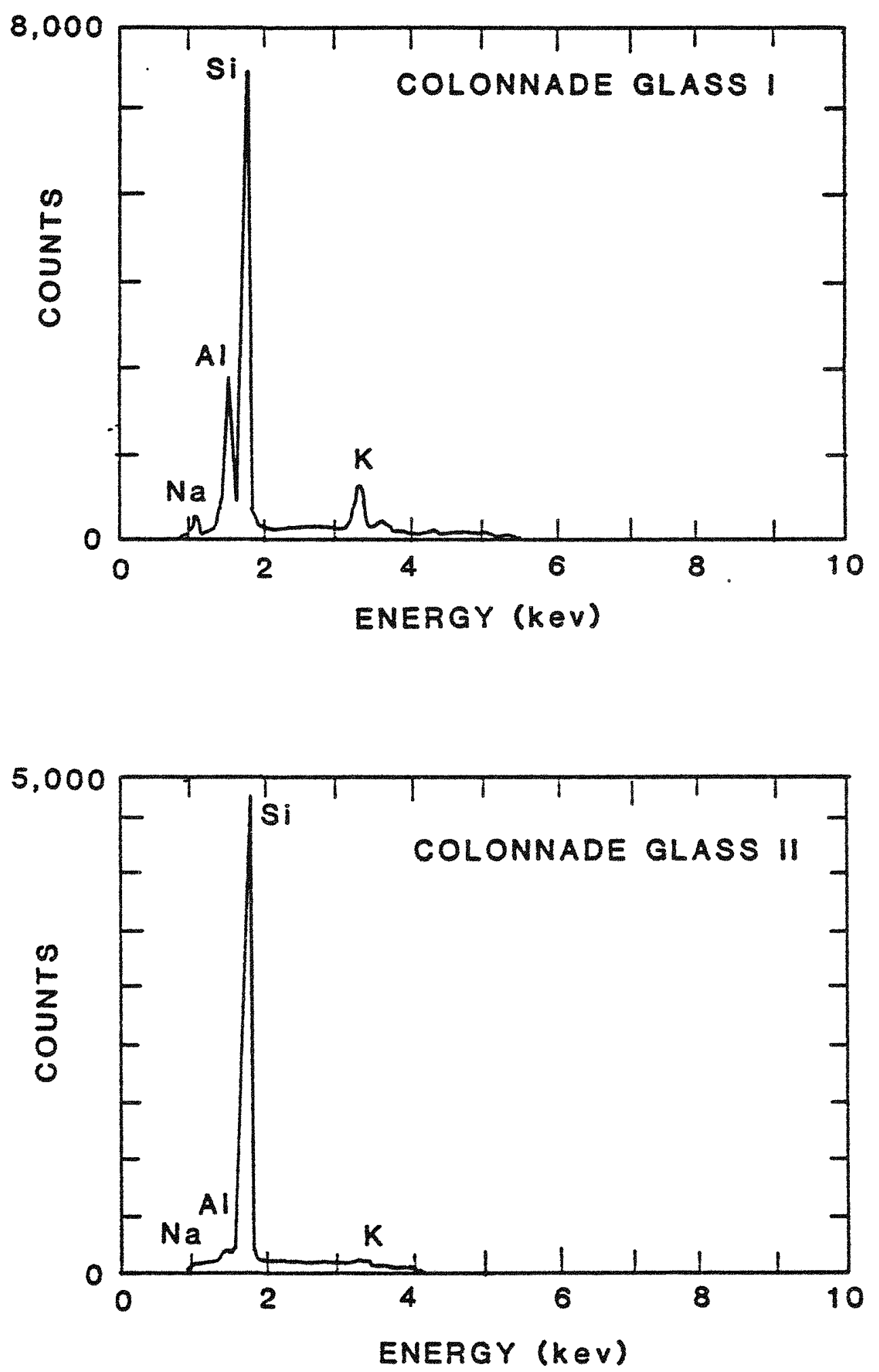

WP8501-90

Figure 14. EDS spectra of two chemically distinct phases in Cohassett colonnade glass (Sample RRL-2, 3173). 
tending toward feldspar and quartz respectively, in these two optically amorphous glass phases.

$X$-ray Diffraction

Differences between Cohassett colonnade basalt and material from the entablature of the flow are apparent in diffractograms of the samples. Diffractograms of Cohassett colonnade (RRL-2, 3173) and entablature RRL-2, 3134) basalts are compared in Figure 15. As in the entablature, the primary constituent of the colonnade basalt is plagioclase feldspar. The diffractogram produced by this phase is nearly identical to that of the feldspar in the entablature, providing evidence of thefr very similar chemistries. The bulk of the remaining diffraction i ines are accounted for by the clinopyroxenes augite and pigeonite. The overall I ine shapes differ from those seen in the entablature diffractogram, and the augite lines appear to have shifted slightly towards smaller interplanar spacings, al lowing better resolution of the pigeonite peaks. The augite peak shifts indicate a change in its chemistry. Both phases match the same reference diffraction patterns as do their counterparts in the entablature, although the augite pattern provides a better match in the colonnade than it does in the entabiature pattern. The clay peak present in the diffractogram of the entablature basalt is also present in the diffractogram of the colonnade basalt. The weaker diffraction peak indicates a smaller quantity of elay is present in the colonnade than in the entablature. No clear evidence for titaniferous magnetite is observed in the diffractograms. The amorphous hump typically produced by $g$ lassy phases is absent, indicating that mesostasis glass is not present in quantities detectable by $X$-ray diffaction.

The colonnade samples collected on the surface differ only slightly from the core sample, as is shown in the comparison of RCC- 2 basalt and core specimen diffractograms in Figure 16. Some compositional variations do apparently occur among surface samples RCC-1, RCC-2, and RCC-3, (Figure 17). The clay contents dfffer among the samples, and the plagloclase in RCC-1 appears to be more albitic, as evidenced by the changes in plagloclase peak positions and intensities. 


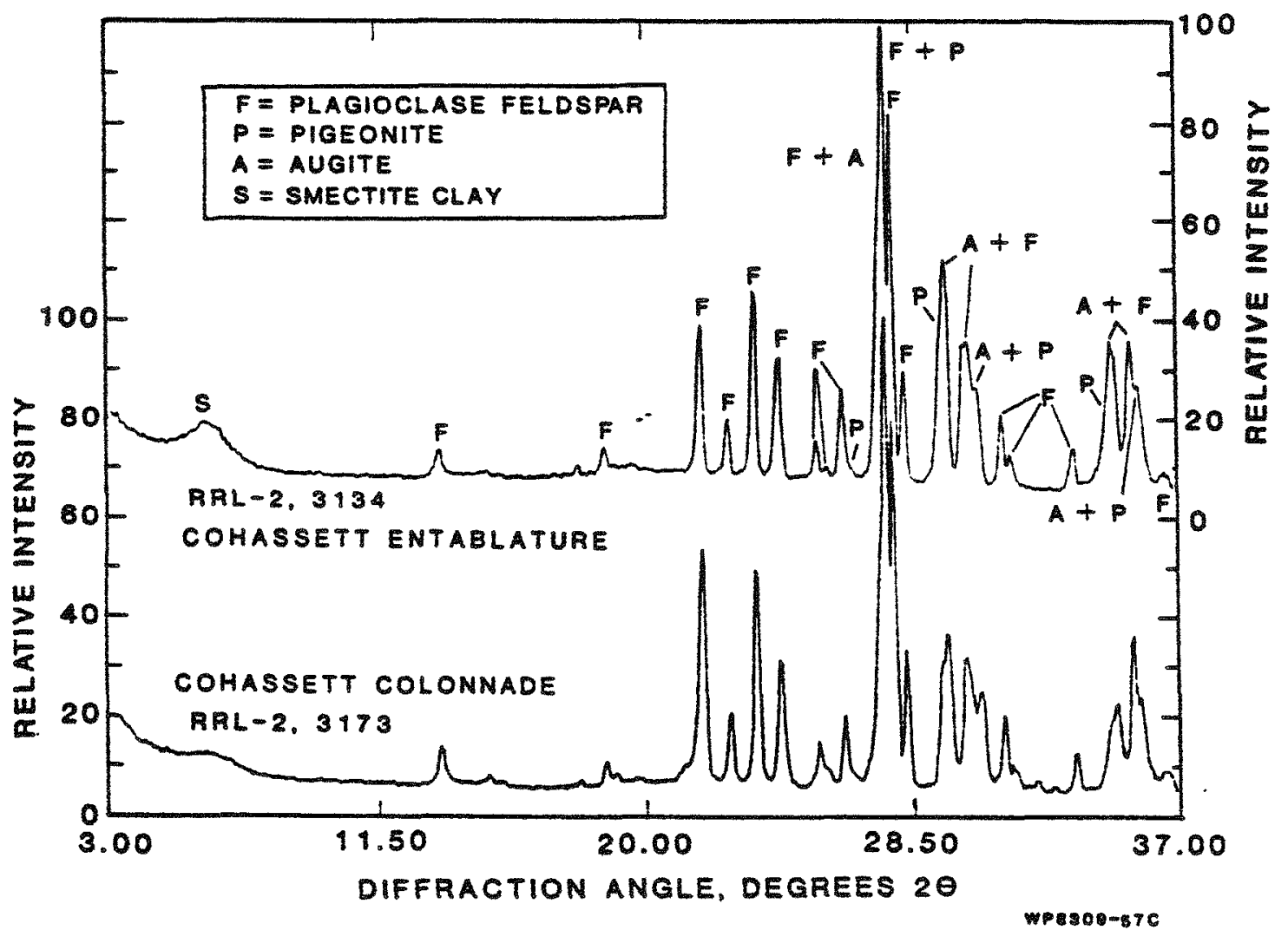

Figure 15. X-ray diffractograms of Cohassett entablature and colonnade samples from core hole RRL-2. Note the differences in the augite peaks, as well as in the intensities of the smectite clay peaks. 


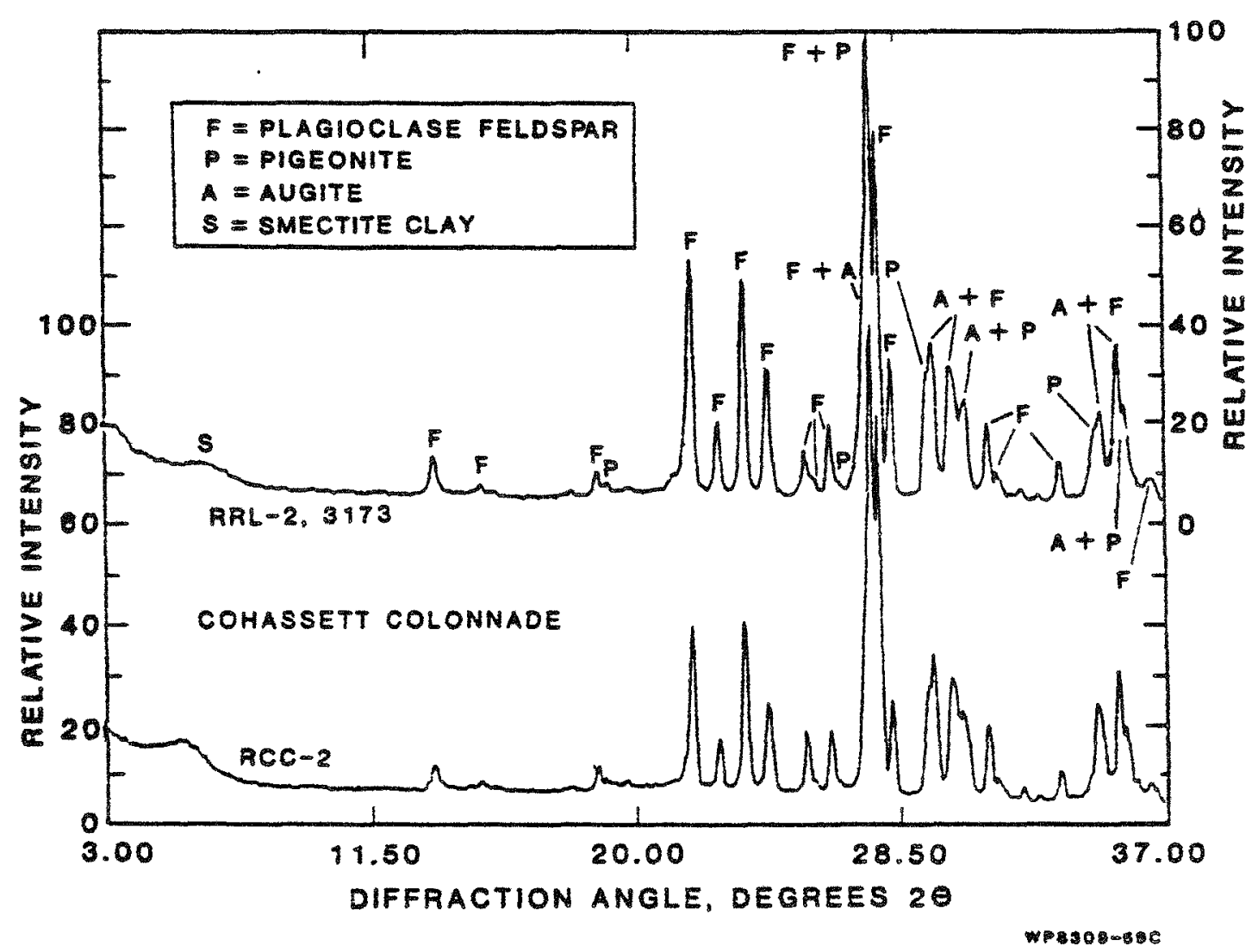

Figure 16. Comparison of X-ray diffractograms of Cohassett colonnade basalt from a core sample (RRL-2, 3173) and a surface sample (RCC-2). Only very minor differences are evident. 


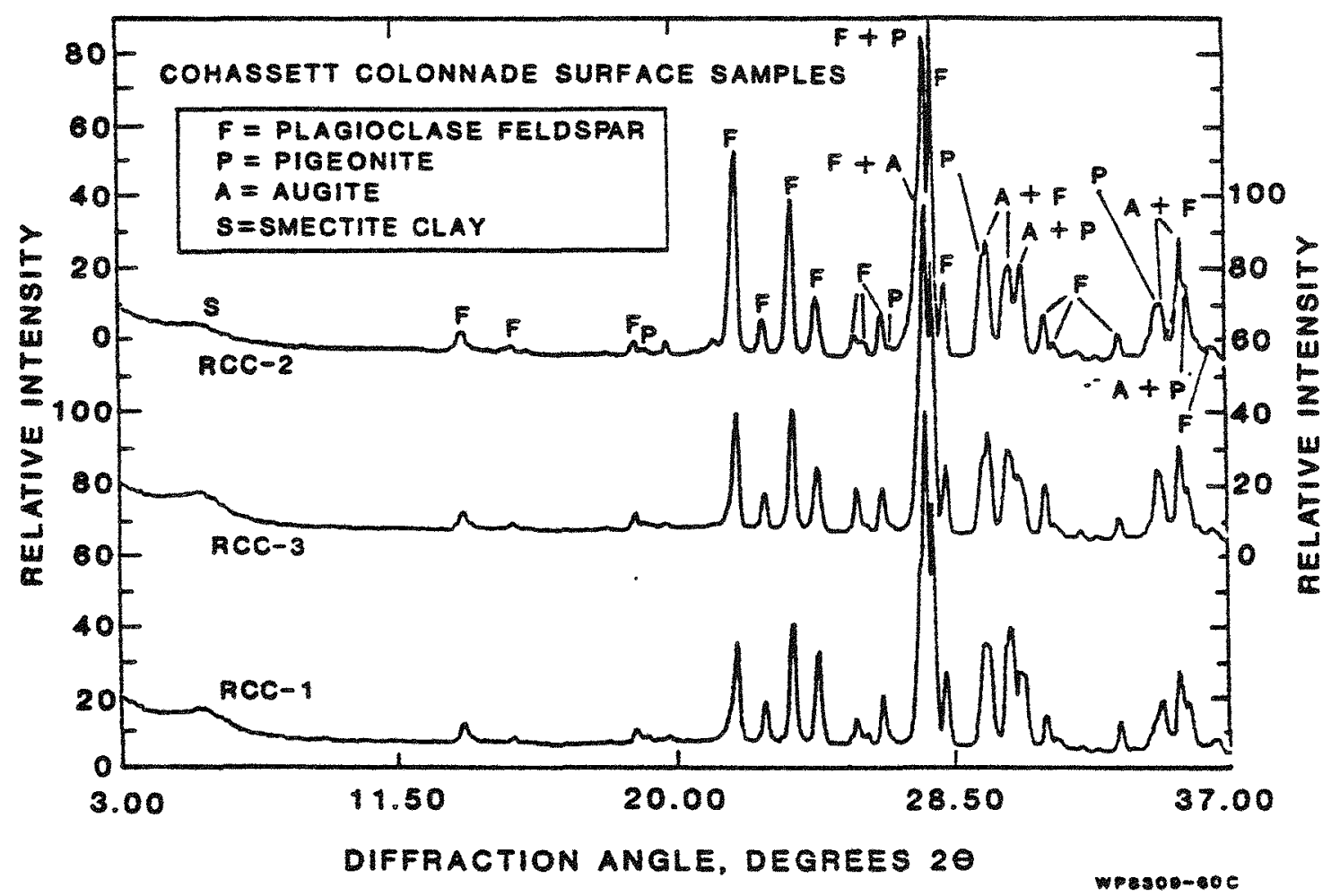

Figure 17. Comparison of X-ray diffractograms from three surface samples of reference Cohassett colonnade basalt. Differences among these patterns are indicative of the small compositional variations observed in this material by other methods. 
$X$-ray Fiuorescence

REV 0

The bulk chemical composition of Cohassett colonnade basalt. as determined by XRF, is given in Table 12. No significant differences exist between the bulk compositions of colonnade and entablature samples, or between samples collected at the surface and from deep or 191 cores.

Summary

The Cohassett colonnade basalt, both at the reference surface site and at depth, resembies the Cohassett entablature in bulk chemical. composition and major mineralogy. The late-stage cooling of the colonnade 'lava was apparentiy slower than that of the entablature lava (Wood and Long, 1984), as indicated by the larger magnetite and apatite crystals and the more "evolved" (higher silicon) glass composition in the colonnade samples. The colonnade glass is a two-phase mixture which displays incipient crystallinity. Surface samples from the reference horizon are very similar to Cohassett colonnade core samples, and should prove to be adequate substitutes in geochemical tests.

\section{ACKNOWLEDGEMENTS}

The authors would like to thank K. R. Fairchild, S. B. Kunkler, and J. R. Smith for assistance in the experimental phase of this investigation. D. G. Horton for a careful peer review, and $K_{0}$ L. Tomac for her cheerful secretarial help. Portions of this document are based on Sections 4.1 .1 and 4.2.2 of Palmer et a ... (1982), and are included here for completeness. 
Al len, C. C.o and M. B. Strope (1983). Microcharacterization of Basalt--Considerations for a Nuclear Waste Reposttory, RHO-BW-SA-294 P, Rockwell Hanford Operations, Richland, Washington.

Long, P. E.o and M. B. Strope (1983). Composition of Augite and Pigeonite in Basa it Elows that are Candidates for a Nuclear Waste Repository, RHO-BW-SA-295 P, Rockwell Hanford Operations, Richland, Washington.

Myers, C. W.. S. M. Price, J. A. Caggiano, M. P. Cochran, W. J. Czimer, N. J. Davidson, R. C. Edwards, K. R. Fecht, G. E. Holmes, M. G. Jones, J. R. Kunk, R. D. Landon, R. K. Ledgerwood, J. T. Lillie, P. E. Long, T. H. Mitche 1 1, E. H: Price, S. P. Reidel, and A. M. Tal 1 man (1979). Geologic Studies of the Columbia Plateau: A Status Report, RHO-BWI-ST-4, Rockwell Hanford Operations, Richland, Washington.

Noonan, A. F., K. Fredriksson, and J. Neien (1981). "Phase Chemistry of the Umtanum Basa 1t. A Reference Repository Host in the Columbia Plateau," pp. 51-58 in Scientific Basis for Nuclear Waste Management, Vol. 3, J. G. Moore, ed., Plenum Press, New York.

Palmer, R. A., G. D. Aden, R. G. Johnston, T. E. Jones, D. L. Lane., and A. F. Noonan, (1982). Characterization of Reference Materials for the Barrier Materials Iest Program, RHO-BW-ST-27P, Rockwe 11 Hanford Operations, Richiand Washington.

PDF (Mineral Powder Diffraction File) (1983). International Centre for Diffraction Data, Swarthmore, PA.

Salter, P. F., L. L. Ames, and J. E. McGarrah (1981). The Sorotion Behzvior of Selected Radionuclides on Columbia River Basalts, RHO-BWI-LD-48, Rockwell Hanford Operations, Richland, Washington.

Wood, B. J., and P. E. Long (1984). Structures, Iextures, and Cool ing Histories of Columbia River Basalt Elows, RHO-BWI-SA-148 A, Rockwe 11 Hanford Operations, Richland, Washington. 